\title{
Core oxidative stress response in Aspergillus nidulans
}

\author{
Tamás Emri ${ }^{1 *}$, Vera Szarvas ${ }^{1}$, Erzsébet Orosz ${ }^{1}$, Károly Antal ${ }^{2}$, HeeSoo Park ${ }^{3}$ Kap-Hoon Han ${ }^{4}$, Jae-Hyuk Yu ${ }^{3}$ \\ and István Pócsi ${ }^{1}$
}

\begin{abstract}
Background: The b-Zip transcription factor AtfA plays a key role in regulating stress responses in the filamentous fungus Aspergillus nidulans. To identify the core regulons of AtfA, we examined genome-wide expression changes caused by various stresses in the presence/absence of AtfA using A. nidulans microarrays. We also intended to address the intriguing question regarding the existence of core environmental stress response in this important model eukaryote.
\end{abstract}

Results: Examination of the genome wide expression changes caused by five different oxidative stress conditions in wild type and the atfA null mutant has identified a significant number of stereotypically regulated genes (Core Oxidative Stress Response genes). The deletion of atfA increased the oxidative stress sensitivity of $A$. nidulans and affected mRNA accumulation of several genes under both unstressed and stressed conditions. The numbers of genes under the AtfA control appear to be specific to a stress-type. We also found that both oxidative and salt stresses induced expression of some secondary metabolite gene clusters and the deletion of atfA enhanced the stress responsiveness of additional clusters. Moreover, certain clusters were down-regulated by the stresses tested.

Conclusion: Our data suggest that the observed co-regulations were most likely consequences of the overlapping physiological effects of the stressors and not of the existence of a general environmental stress response. The function of AtfA in governing various stress responses is much smaller than anticipated and/or other regulators may play a redundant or overlapping role with AtfA. Both stress inducible and stress repressive regulations of secondary metabolism seem to be frequent features in A. nidulans.

Keywords: Aspergillus nidulans, Oxidative stress, General/environmental stress response, bZIP-type transcription factors, AtfA, Secondary metabolism

\section{Background}

Stress is defined as a change in the environment that results in an internal response in living organisms. All life forms respond to stress, which involves adaptive changes throughout an organism to restore the internal cellular balance in physiological systems. Many aspects of the cellular stress response are not specific to a given stress, as cells monitor stress based on macromolecular damage not the type of stress that causes such damage [1].

The kingdom Fungi have evolved with powerful tools for environmental stress sensing, signaling and adaptation, hence, they can occupy versatile ecological niches $[2,3]$. A

\footnotetext{
*Correspondence: emri.tamas@science.unideb.hu

${ }^{1}$ Department of Biotechnology and Microbiology, Faculty of Science and Technology, University of Debrecen, P.O. Box 63, H-4032 Debrecen, Hungary Full list of author information is available at the end of the article
}

wealth of information is available on the oxidative stress response systems of the budding yeast Saccharomyces cerevisiae [4-7] and the fission yeast Schizosaccharomyces pombe [8], which makes the use of yeast-based models popular when the stress response systems of other fungi are studied irrespective of interspecial evolutionary distances [9].

Cross-stress protection phenomena, which prepare fungi to combat more severe forthcoming environmental stress of either the same type or a completely different type, is also wide-spread among fungi $[4,10-14]$ and obviously contributes to the ecological success of today's fungi $[2,3]$.

The molecular mechanism of such cross-protection phenomena may be based on a group of genes coregulated under various types of environmental stress 
which are called "Environmental Stress Response" or ESR genes $[2,15]$. ESR genes have been identified in $S$. cerevisiae [15], S. pombe [16], Candida albicans [17] and Candida glabrata [18] although their number and regulation varies within an unexpectedly wide spectrum. For example, Msn2/4 C2H2 zinc finger type transcription factors are the master regulators of ESR in both $S$. cerevisiae (size of ESR is $~ 900$ genes [15]) and C. glabrata (782 genes [18]) meanwhile the bZIP-type (basic leucine zipper DNA interactive domain containing) transcription factor Atf1 $[19,20]$ is the general 'all purpose' regulator of ESR in fission yeast ( 140 ESR genes [16]). In C. albicans, the existence of ESR was debated [21] but a relatively small group of ESR genes (62 genes) was identified at last under the control of Hog1 mitogen activated protein kinase (MAPK) $[17,22]$. Importantly, the way of counting ESR genes has not been standardized yet and seems to be dependent on the dose of stress $[17,21,22]$ and the rate of growth [23, 24]. Furthermore, global transcriptional responses to oxidative stress and their regulations were dependent on the type and dose of stress in S. pombe [25], and also on the presence or absence of another bZIP-type transcription factor Pcr1, which form heterodimers with Atf1 [26-28].

More recent data published by Berry and Gasch [12] assigned a basically preparative role to ESR against impending stress in budding yeast. Moreover the activation of several different sets of stress response genes by various mild stress conditions may provide budding yeast with satisfactory cross-protection against a given type of severe environmental stress [13]. This observation may help us to explain the general stress tolerance of oxidative stress tolerant strains of C. albicans [29] although the size of ESR is small in this opportunistic human pathogen [17].

Interestingly, although it is almost impossible to overestimate the biomedical, economical and ecological significance of the filamentous fungus genus Aspergillus [30-35] the information available on the oxidative stress defense systems of these organisms is still limited [9, 36-40], and no data on the existence (or the absence) of Aspergillus ESR has been published to the best of our knowledge. A deeper understanding of how the stress response systems of the Aspergilli work may help us, e.g. in the identification of novel antifungal drug targets against opportunistic human pathogens like Aspergillus fumigatus $[40,41]$ or in the biological control of mycotoxin productions by toxigenic Aspergillus species [42-44].

For our current study, we selected the mycotoxin (e.g. sterigmatocystin) producer model organism Aspergillus nidulans, which has a complex and robust stress response system incorporating both budding yeast and fission yeast homolog elements, but the overall view is more fission yeast-like [9]. Considering previous literature data, the SakA/HogA MAPK activated AtfA transcription factor, a true functional ortholog of fission yeast's Atf1, may play a pivotal role in the orchestration of the stress responses of this filamentous fungus [36, 45-49]. Nevertheless, the deletion of atfA did not result in any osmotic stress sensitive phenotype in $A$. nidulans $[46,48]$ but decreased the oxidative stress tolerance of the fungus [48-50]. In spite of the lack of the relevant phenotypes in the gene deletion mutants, AtfA plays an important role in the regulation of global translational changes under osmotic stress, and situates down-stream of SakA/HogA MAPK [47, 49]. In another study, Balázs et al. [48] challenged the hypothesis that a fission yeast-like stress response exists in $A$. nidulans because certain important elements of the oxidative and osmotic stress defense systems were controlled by AtfA but in a stress-specific manner. E.g. catB coding for catalase B and $g f d B$ encoding glycerol-3-phosphate dehydrogenase $\mathrm{B}$, both under AtfA control, were up-regulated by oxidative $\left(\mathrm{H}_{2} \mathrm{O}_{2}\right.$ and $t$-butylhydroperoxide; $\left.t \mathrm{BOOH}\right)$ and osmotic $(\mathrm{NaCl})$ stress, respectively, but not vice versa. It is worth noting that AtfA also possesses important functions in the development of conidiophores [49] and in the stabilization of asexual spores against oxidative and heat stress [46]. Importantly, other Atf1 (and AtfA) homologs with significant physiological functions have been characterized more recently in other Aspergilli including Aspergillus oryzae (AtfA and AtfB [51, 52]) and Aspergillus fumigatus (AtfA [53, 54]) and in other ascomycetes, for example Claviceps purpurea (CPTF1 [55], Neuropsora crassa (ATF-1 [56]), Magnaporthe oryzae (Moatf1 [57]), Fusarium graminearum (Fgatf1 [58]), Fusarium oxysporum f. sp. cubense (Foatf1 [59]) and Penicillium marneffei (AtfA [60]), which gives further actuality to this study.

Considering previous literature data on A. nidulans AtfA, we aimed at (i) recording and comparing global transcriptional changes in $A$. nidulans $\triangle a t f A$ gene deletion mutant and control cultures exposed to various types and doses of oxidative stress and also to osmotic stress using a whole-genome-based 60-mere DNA microarray [61], (ii) comparing these transcriptome data with the results of previous EST-based DNA microarray [36] and proteome [62] studies, (iii) defining a group of genes co-regulated under oxidative stress (Core Oxidative Stress Response or COSR genes) or under environmental stress (ESR genes), (iv) estimating the importance of AtfA transcription factor under unstressed conditions and in the regulation of COSR and ESR and (v) analyzing the impact of various stress conditions and atfA deletion on the regulation of various secondary metabolite gene clusters.

\section{Results}

An $A$. nidulans $\triangle a t f A$ gene deletion strain and the appropriate control strain were generated. The $\triangle a t f A \mathrm{mu}-$ tant was more sensitive to menadione sodium bisulfite (MSB), $\mathrm{H}_{2} \mathrm{O}_{2}, t$-butylhydroperoxide $(t \mathrm{BOOH})$, diamide 
(but not to $\mathrm{NaCl}$ ) than the control strain (Fig. 1, Table 1) at all stressor concentrations tested, which was in agreement with previous observations by Balázs et al. [48].

Genome-wide expression changes caused by different stress conditions were studied in $\triangle a t f A$ and control strains. The applied stressor concentrations $(0.12 \mathrm{mM}$ $\mathrm{MSB}, 5$ and $75 \mathrm{mM} \mathrm{H}_{2} \mathrm{O}_{2}, 0.8 \mathrm{mM} \mathrm{tBOOH}, 1.8 \mathrm{mM}$ diamide and $0.6 \mathrm{M} \mathrm{NaCl}$ ) were comparable to those used previously by Hagiwara et al. [46], Lara-Rojas et al. [49] and Yin et al. [63]. The strains continued their growths in the presence of the stress generating agents as presented in Table 2. Interestingly, a full recovery in growth was reached in $10 \mathrm{~h}$ after $\mathrm{H}_{2} \mathrm{O}_{2}$ exposures (both 5 and $75 \mathrm{mM}$ ) in the control strain meanwhile a lower biomass production was recorded in cultures containing MSB, diamide or $\mathrm{NaCl}$ (appr. 22.5-35.5 \% less biomass in comparison to untreated control). A more significant growth reduction was only recorded in cultures exposed to $t \mathrm{BOOH}$ (appr. $61.3 \%$ less biomass). Importantly, per cent growth reductions found in $\triangle a t f A$ cultures (full recovery for $1-\mathrm{H}_{2} \mathrm{O}_{2}$, appr. 24.1-34.5\% growth reductions for $\mathrm{MSB}$, diamide and $\mathrm{NaCl}$, and $72.4 \%$ less biomass for $t \mathrm{BOOH}$ treated cultures) were quite similar to those found in control cultures with the exception of $75 \mathrm{mM}$ $\mathrm{H}_{2} \mathrm{O}_{2}$, where a $34.5 \%$ growth reduction indicated a somewhat slower recovery than that observed in h$\mathrm{H}_{2} \mathrm{O}_{2}$-exposed control cultures (Table 2). Taking into consideration these growth reductions, $t \mathrm{BOOH}$. MSB, diamide and $\mathrm{NaCl}$ treatments were regarded "severe" stress conditions meanwhile $\mathrm{H}_{2} \mathrm{O}_{2}$-initiated stress was considered "mild" (at least for the control strain).

Importantly, good correlations with correlation coefficients between 0.71-0.88 were found between DNA chip-based gene expression data and the qRT-PCRbased gene expression validation data gained with 67 gene specific primer pairs (Additional file 1: Table S1). On the other hand, we found only weak correlations with correlation coefficients of pairwise comparisons less than 0.2 (data not shown) between current gene expression data sets and the data coming from our earlier study, which was based on DNA microarrays containing 3533 unique PCR-amplified probes [36]. However, some co-regulated genes were identified, which are summarized in Additional file 2: Table S2 and which include AN2846 $(g p x A)$ putative glutathione peroxidase gene (up-regulated after $0.5 \mathrm{~h} \mathrm{MSB}$ and diamide treatments) as well as the AN1182 (benA) B-tubulin, AN6632 putative $40 \mathrm{~S}$ ribosomal protein and AN6181 putative 60S ribosomal protein genes, all of which were down-regulated after $0.5 \mathrm{~h}$ MSB treatments in both studies.

We also compared the new whole-genome-based DNA chip data with our previous proteome data set [62], and it was found that out of the 153 stress-responsive proteins identified in $0.8 \mathrm{mM} \mathrm{MSB}$ treated cultures at $6 \mathrm{~h}$ exposure time 59 (39\%) behaved in line with the gene expression changes recorded in this study (with at least four-times changes in their transcriptions) meanwhile in the case of 35 (23\%) proteins the proteome and transcriptome level changes were significant but just in the opposite sense (data not shown). Some notable co-regulated genes are summarized in Additional file 3: Table S3 and include AN2846 (gpxA), encoding a putative glutathione peroxidase, AN3581 $(\operatorname{tr} x R)$, coding for a putative thioredoxin reductase, which stress response elements were up-regulated at the levels of both transcription and translation after MSB exposures as well as AN10223, a putative peroxiredoxin gene and AN7388 (catD), a putative catalase-peroxidase gene, which genes and also their protein products were equally down-regulated under MSB treatments.

\section{COSR and cross-stress adaptations}

"Severe" oxidative stress conditions generated by MSB, $t \mathrm{BOOH}$, diamide (but not by $\mathrm{H}_{2} \mathrm{O}_{2}$ ) exposures caused

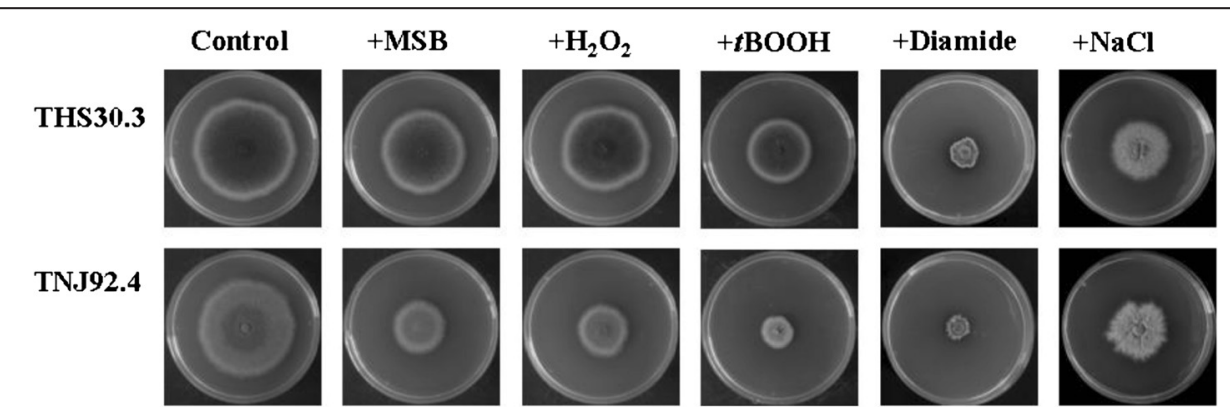

Fig. 1 Comparison of the stress sensitivities of control and $\triangle a t f A$ Aspergillus nidulans strains. Plates were point-inoculated with freshly grown conidia $\left(10^{5}\right.$ conidia in $5 \mu$ laliquots of $0.9 \% \mathrm{NaCl}, 0.01 \%$ Tween 80 ) and were incubated at $37{ }^{\circ} \mathrm{C}$ for $5 \mathrm{~d}$ (Yin et al., 2013 [63]). All assays were carried out in triplicates, and representative photos are presented here. The stress sensitivites of the $\Delta a t f A$ strain were always higher than those of the control at any concentrations of the oyidative stress generating agents tested. In contrast, there was no difference between the relative growths of the mutant and control strains when exposed to $\mathrm{NaCl}$. The employed stressor concentrations were: $t \mathrm{BOOH}$ : $0.8 \mathrm{mM}, \mathrm{H}_{2} \mathrm{O}_{2}: 6.0 \mathrm{mM}$, MSB: $0.12 \mathrm{mM}$, diamide: $2.0 \mathrm{mM}$ and $\mathrm{NaCl}$ : $0.6 \mathrm{M}$. Representative photos are presented 
Table 1 Stress sensitivity of the control and the $\triangle$ atfA strains in surface cultures

\begin{tabular}{lcclll}
\hline Growth $^{a}$ & \multicolumn{5}{l}{ Stress exposures } \\
\cline { 2 - 6 } & $\begin{array}{l}\mathrm{MSB} \\
(0.12 \mathrm{mM})\end{array}$ & $\begin{array}{l}\mathrm{H}_{2} \mathrm{O}_{2} \\
(6 \mathrm{mM})\end{array}$ & $\begin{array}{l}\mathrm{tBOOH} \\
(0.8 \mathrm{mM})\end{array}$ & $\begin{array}{l}\text { Diamide } \\
(2 \mathrm{mM})\end{array}$ & $\begin{array}{l}\mathrm{NaCl} \\
(0.6 \mathrm{M})\end{array}$ \\
\hline $\begin{array}{l}\text { Colony diameter } \\
\text { (\%) (control strain) }\end{array}$ & $82 \pm 3$ & $84 \pm 6$ & $70 \pm 8$ & $34 \pm 3$ & $56 \pm 4$ \\
$\begin{array}{l}\text { Colony diameter } \\
\text { (\%) (4atfA strain) }\end{array}$ & $52 \pm 3^{*}$ & $54 \pm 6^{*}$ & $41 \pm 6^{*}$ & $26 \pm 4^{*}$ & $57 \pm 4$ \\
\hline
\end{tabular}

*Significant difference between the two strains was demonstrated using the Student's t-test $(p<0.05)$

${ }^{a}$ Growth was characterized with the diameter of the colonies recorded at $5 \mathrm{~d}$. Colony diameters are given in the percentage of the colony diameter measured in untreated cultures. Mean \pm S.D. values, calculated from 4 independent experiments are presented

up-regulation or down-regulation of more than 1000 genes each in both the control and the $\triangle a t f A$ gene deletion strains (Table 3). In contrast, "mild" stress initiated by $\mathrm{H}_{2} \mathrm{O}_{2}$ (5 and $75 \mathrm{mM}$ ) as well as by $\mathrm{NaCl}$ (high-osmolarity stress) had typically less effect on the transcriptome with less than or around 1000 genes up-regulated or downregulated (Tables 3 and 4). The numbers of co-regulated genes in different stress-exposed control and $\triangle a t f A$ cultures indicate clearly that the more stressors were included in the comparison of the global transcriptional changes the less co-regulated genes were found (Tables 3 and 4).

COSR genes were defined as genes showing unidirectional transcriptional changes under the three "severe" oxidative stress conditions tested (stress conditions generated by $\mathrm{MSB}, t \mathrm{BOOH}$ and diamide). Relying on these premises, the numbers of COSR genes were 873 and 729 in the control and $\triangle a t f A$ strains, respectively (Table 3 ). The subsequent inclusion of either $\mathrm{h}-\mathrm{H}_{2} \mathrm{O}_{2}$ or $\mathrm{NaCl}$ or even concomitantly both stress treatment data sets into the comparative analysis of the transcriptional changes reduced markedly the number of core stress response genes (Table 3). The inclusion of all stress treatments $\left(\mathrm{l}-\mathrm{H}_{2} \mathrm{O}_{2}, \mathrm{~h}-\mathrm{H}_{2} \mathrm{O}_{2}\right.$ and also $\left.\mathrm{NaCl}\right)$ almost completely emptied the group of core stress response genes; only 13 and 18 genes (Table 3) showed unidirectional transcriptional changes in all stress exposure experiments in the control strain and the $\triangle a t f A$ strain, respectively. The pairwise similarities between transcriptome profiles (Fig. 2, Additional file 4: Table S4) as well as the great number of genes showing transcriptional changes only in one stress treatment (Table 3) also suggested that the different stressors had characteristic stress-specific effects on the transcriptome.

Regarding the two $\mathrm{H}_{2} \mathrm{O}_{2}$ stress treatments, the majority $(78-85 \%)$ of genes regulated by $1-\mathrm{H}_{2} \mathrm{O}_{2}$ exposure were also regulated by $h-\mathrm{H}_{2} \mathrm{O}_{2}$ exposure in the control strain (Table 4). Interestingly, the overlap between the effects of the two treatments was significantly smaller (47-50\%) in case of the $\triangle a t f A$ strain (Table 4).

A significant portion of COSR genes was uncharacterized and more than $50 \%$ of the COSR genes in the control strain did not appear in the group of COSR genes defined in the $\triangle a t f A$ mutant (Additional file 5: Table S5). For example, napA (AN7513) coding for a bZIP-type oxidative stress response regulatory transcription factor [50] was only part of the COSR genes in the THS30.3 control strain meanwhile rsmA (AN4562), encoding another bZIP-type transcription factor involved in the regulation of secondary metabolism [63], was a COSR gene in both the control and the $\triangle a t f A$ mutant strains concomitantly (Additional file 5: Table S5). Induction of rsm $A$ in both the control and the mutant strains as well as a significantly higher induction of napA in the control than in the mutant strain under MSB, $\mathrm{tBOOH}$ and diamide stress treatments was also verified by qRT-PCR experiments (Additional file 1: Table S1).

In order to find significant shared GO terms among those systematically used to describe COSR genes, the GO Term Finder of Aspergillus Genome Database (http:// www.aspergillusgenome.org) was used. Importantly, no significant shared GO term was found in the group of genes incorporating up-regulated COSR genes in the control strain. On the other hand, several GO terms related to cell cycle (e.g. replication, cytoskeleton functions, nuclear and cell division) as well as the GO terms "ribosome biogenesis" and "sterol metabolic process" were significantly shared in the group of down-regulated COSR genes (Additional file 6: Table S6). In contrast, the GO term "cell redox homeostasis" and several other GO terms related to ribosome biogenesis were significantly shared in the sets of up-regulated and down-regulated genes, respectively, in the $\triangle$ atfA gene deletion strain (Additional file 6: Table S6).

Table 2 Increases in the dry cell mass (DCM) values determined under various stress conditions in cultures of the control and the $\triangle a t f A$ strains

\begin{tabular}{|c|c|c|c|c|c|c|c|}
\hline \multirow[t]{2}{*}{ Biomass gains $^{a}$} & \multicolumn{7}{|c|}{ Stress exposures ${ }^{b}$} \\
\hline & No stress & MSB & $\mathrm{I}-\mathrm{H}_{2} \mathrm{O}_{2}$ & $\mathrm{~h}-\mathrm{H}_{2} \mathrm{O}_{2}$ & $\mathrm{tBOOH}$ & Diamide & $\mathrm{NaCl}$ \\
\hline$\Delta \mathrm{DCM}\left(\mathrm{g} \mathrm{I}^{-1}\right)^{2}$ (control strain) & $3.1 \pm 0.4$ & $2.1 \pm 0.3^{*}$ & $3.1 \pm 0.4$ & $3.0 \pm 0.5$ & $1.2 \pm 0.2^{*}$ & $2.4 \pm 0.3^{*}$ & $2.0 \pm 0.3^{*}$ \\
\hline$\Delta \mathrm{DCM}\left(\mathrm{g} \mathrm{I}^{-1}\right)^{2}(\Delta a t f A)$ & $2.9 \pm 0.4$ & $2.2 \pm 0.3^{*}$ & $2.8 \pm 0.3$ & $1.9 \pm 0.3^{*}$ & $0.8 \pm 0.1^{*}$ & $2.2 \pm 0.3^{*}$ & $1.9 \pm 0.2^{*}$ \\
\hline
\end{tabular}

*Significant difference between untreated and treated cultures was demonstrated using the Student's t-test $(p<0.05)$

${ }^{a}$ Changes in dry cell mass (DCM) values were recorded $10 \mathrm{~h}$ after stress treatments. Mean \pm S.D. values, calculated from 4 independent experiments are presented ${ }^{b}$ The following stressor concentrations were employed in these experiments: MSB: $0.12 \mathrm{mM}$, low concentration (I)- $\mathrm{H}_{2} \mathrm{O}_{2}: 5 \mathrm{mM}$, high concentration (h)- $\mathrm{H}_{2} \mathrm{O}_{2}$ :

$75 \mathrm{mM}, \mathrm{tBOOH}: 0.8 \mathrm{mM}$, diamide: $1.8 \mathrm{mM}$ and $\mathrm{NaCl}: 0.6 \mathrm{M}$ 
Table 3 Number of co-regulated genes in stress-exposed control and $\triangle a t f A$ cultures

\begin{tabular}{|c|c|c|c|c|c|c|c|}
\hline \multirow[t]{2}{*}{ Transcriptional changes $^{a}$} & \multicolumn{7}{|c|}{ Stress exposures ${ }^{\mathrm{b}}$} \\
\hline & $\mathrm{MSB}$ & $\mathrm{MSB} t \mathrm{BOOH}$ & MSB tBOOH diamide & $\mathrm{MSB} t \mathrm{BOOH}$ diamide+ $\mathrm{h}-\mathrm{H}_{2} \mathrm{O}_{2}$ & $\mathrm{MSB} t \mathrm{tOOH}$ diamide $+\mathrm{NaCl}$ & $\mathrm{MSB}$ tBOOH diamide+ $\mathrm{h}-\mathrm{H}_{2} \mathrm{O}_{2}$ and $\mathrm{NaCl}$ & $A \|^{C}$ \\
\hline \multicolumn{8}{|l|}{ THS30.3 control strain } \\
\hline \multicolumn{8}{|l|}{ Up-regulated genes } \\
\hline$>2 x$ increases in 6 stresses & & & & & & & 7 \\
\hline$>2 x$ increases in 5 stresses & & & & & & 51 & 88 \\
\hline$>2 x$ increases in 4 stresses & & & & 161 & 84 & 226 & 221 \\
\hline$>2 x$ increases in 3 stresses & & & 393 & 414 & 503 & 535 & 523 \\
\hline$>2 x$ increases in 2 stresses & & 699 & 793 & 856 & 1031 & 1012 & 1004 \\
\hline$>2 x$ increase in 1 stress & 1574 & 1542 & 2052 & 2018 & 2007 & 1925 & 1923 \\
\hline \multirow[t]{2}{*}{ Sum: } & 1574 & 2241 & 3238 & 3449 & 3625 & 3749 & 3766 \\
\hline & MSB only & tBOOH only & Diamide only & h- $\mathrm{H}_{2} \mathrm{O}_{2}$ only & $\mathrm{NaCl}$ only & & $\mathrm{I}-\mathrm{H}_{2} \mathrm{O}_{2}$ only \\
\hline$>2 x$ increases & 1574 & 1366 & 1877 & 799 & 1097 & & 153 \\
\hline \multicolumn{8}{|l|}{ Down-regulated genes } \\
\hline$>2 x$ decreases in 6 stresses & & & & & & & 6 \\
\hline$>2 x$ decreases in 5 stresses & & & & & & 65 & 84 \\
\hline$>2 x$ decreases in 4 stresses & & & & 103 & 194 & 278 & 300 \\
\hline$>2 x$ decreases in 3 stresses & & & 480 & 530 & 544 & 543 & 580 \\
\hline$>2 x$ decreases in 2 stresses & & 786 & 960 & 1021 & 985 & 1031 & 1069 \\
\hline$>2 x$ decrease in 1 stress & 1696 & 1563 & 1799 & 1904 & 1813 & 1852 & 1763 \\
\hline \multirow[t]{2}{*}{ Sum: } & 1696 & 2349 & 3239 & 3558 & 3536 & 3769 & 3802 \\
\hline & MSB only & tBOOH only & Diamide only & h- $\mathrm{H}_{2} \mathrm{O}_{2}$ only & $\mathrm{NaCl}$ only & & $\mathrm{I}-\mathrm{H}_{2} \mathrm{O}_{2}$ only \\
\hline$>2 x$ decreases & 1696 & 1441 & 2022 & 789 & 1032 & & 317 \\
\hline \multicolumn{8}{|l|}{ TNJ 92.4 $\triangle a t f A$ strain } \\
\hline \multicolumn{8}{|l|}{ Up-regulated genes } \\
\hline$>2 x$ increases in 6 stresses & & & & & & & 8 \\
\hline$>2 x$ increases in 5 stresses & & & & & & 39 & 63 \\
\hline$>2 x$ increases in 4 stresses & & & & 192 & 69 & 233 & 235 \\
\hline$>2 x$ increases in 3 stresses & & & 289 & 331 & 379 & 387 & 399 \\
\hline$>2 x$ increases in 2 stresses & & 561 & 850 & 834 & 951 & 939 & 1006 \\
\hline$>2 x$ increase in 1 stress & 1001 & 1781 & 2103 & 2104 & 2138 & 2141 & 2149 \\
\hline \multirow[t]{2}{*}{ Sum: } & 1001 & 2342 & 3242 & 3461 & 3534 & 3739 & 3860 \\
\hline & MSB only & tBOOH only & Diamide only & h- $\mathrm{H}_{2} \mathrm{O}_{2}$ only & $\mathrm{NaCl}$ only & & $\mathrm{I}-\mathrm{H}_{2} \mathrm{O}_{2}$ only \\
\hline$>2 x$ increases & 1001 & 1902 & 1767 & 863 & 774 & & 354 \\
\hline
\end{tabular}


Table 3 Number of co-regulated genes in stress-exposed control and $\triangle a t f A$ cultures (Continued)

Down-regulated genes

$>2 x$ decreases in 6 stresses

$>2 x$ decreases in 5 stresses

$>2 x$ decreases in 4 stresses

$>2 x$ decreases in 3 stresses

$>2 x$ decreases in 2 stresses

$>2 x$ decrease in 1 stress

Sum:

$\begin{array}{lll} & 440 & 360 \\ 740 & 918 & 882\end{array}$

882

$\begin{array}{llll}1050 & 1354 & 1523 & 1510\end{array}$

$1050 \quad 2094 \quad 2881-3042$

MSB only $t \mathrm{BOOH}$ only Diamide only $\mathrm{h}-\mathrm{H}_{2} \mathrm{O}_{2}$ only

$1784 \quad 1845$

835

$\begin{array}{ll}111 & 10 \\ 289 & 123 \\ 531 & 310 \\ 779 & 546 \\ 1497 & 823 \\ 3207 & 1489 \\ & 3301 \\ & 1-\mathrm{H}_{2} \mathrm{O}_{2} \text { only } \\ & 329\end{array}$

$>2 x$ decreases

1050

${ }^{a}$ Numbers of genes with at least two-fold increase or decrease in their transcriptions under the specified stress conditions are presented for both the control and the $\triangle a t f A$ strains

${ }^{\mathrm{b}}$ Stressor concentrations are presented in footnotes to Table 2

${ }^{\mathrm{C}} \mathrm{MSB}, \mathrm{tBOOH}$, diamide, $\mathrm{I}-\mathrm{H}_{2} \mathrm{O}_{2}, \mathrm{~h}-\mathrm{H}_{2} \mathrm{O}_{2}$ and $\mathrm{NaCl}$ stress treatments 
Table 4 Number of co-regulated genes in $\mathrm{H}_{2} \mathrm{O}_{2}$-exposed control and $\triangle$ atfA cultures

\begin{tabular}{|c|c|c|c|c|c|c|}
\hline \multirow{3}{*}{$\begin{array}{l}\text { Transcriptional } \\
\text { changes }^{a}\end{array}$} & \multicolumn{6}{|l|}{ Strain } \\
\hline & \multicolumn{3}{|c|}{ THS30.3 control strain } & \multicolumn{3}{|c|}{ TNJ 92.4 $\triangle$ atfA strain } \\
\hline & $\begin{array}{l}\text { Up-regulated } \\
\text { genes }\end{array}$ & $\begin{array}{l}\text { Down-regulated } \\
\text { genes }\end{array}$ & $\begin{array}{l}\text { Up- or down-regulated } \\
\text { genes }\end{array}$ & $\begin{array}{l}\text { Up-regulated } \\
\text { genes }\end{array}$ & $\begin{array}{l}\text { Down-regulated } \\
\text { genes }\end{array}$ & $\begin{array}{l}\text { Up- or down-regulated } \\
\text { genes }\end{array}$ \\
\hline $\mathrm{I}-\mathrm{H}_{2} \mathrm{O}_{2}$ & 153 & 317 & 470 & 354 & 329 & 683 \\
\hline h- $\mathrm{H}_{2} \mathrm{O}_{2}$ & 799 & 789 & 1588 & 863 & 835 & 1698 \\
\hline at least in one of them & 833 & 835 & 1668 & 1050 & 999 & 2049 \\
\hline in both of them ${ }^{b}$ & $119(0.78)$ & $271(0.85)$ & $390(0.83)$ & $167^{*}(0.47)$ & $165^{*}(0.50)$ & $332 *(0.49)$ \\
\hline
\end{tabular}

*The number of genes regulated in both $\mathrm{H}_{2} \mathrm{O}_{2}$ experiments in respect to the number of genes regulated by l- $\mathrm{H}_{2} \mathrm{O}_{2}$ treatment is significantly smaller in the $\triangle a t f A$ mutant than in the control strain according to the Fisher's exact test $(p<0.05)$

${ }^{a}$ Numbers of genes with at least two-fold increase or decrease in their transcriptions under the specified stress conditions are presented for both the control and the $\triangle$ atfA strains. Stressor concentrations are presented in footnotes to Table 2

${ }^{b}$ Numbers of genes regulated in both experiments are given. The number of genes regulated in both experiment/number of genes regulated in the presence of $\mathrm{I}-\mathrm{H}_{2} \mathrm{O}_{2}$ ratios are also given in parenthesis

Although only few core stress response genes (Table 3) were found in both the control and the $\triangle a t f A$ strains the stress responses still shared some common motives when the physiological functions of the up-regulated and down-regulated genes were compared. Among the significant shared GO terms "sterol metabolic process" (MSB, l- $\mathrm{H}_{2} \mathrm{O}_{2}$, h- $\mathrm{H}_{2} \mathrm{O}_{2}$, $\mathrm{tBOOH}$ and diamide) and "ribosome biogenesis" (MSB, h- $\mathrm{H}_{2} \mathrm{O}_{2}, \mathrm{tBOOH}$, diamide and $\mathrm{NaCl}$ ) were characteristic for down regulated gene, meanwhile "branched-chain amino acid biosynthetic process"

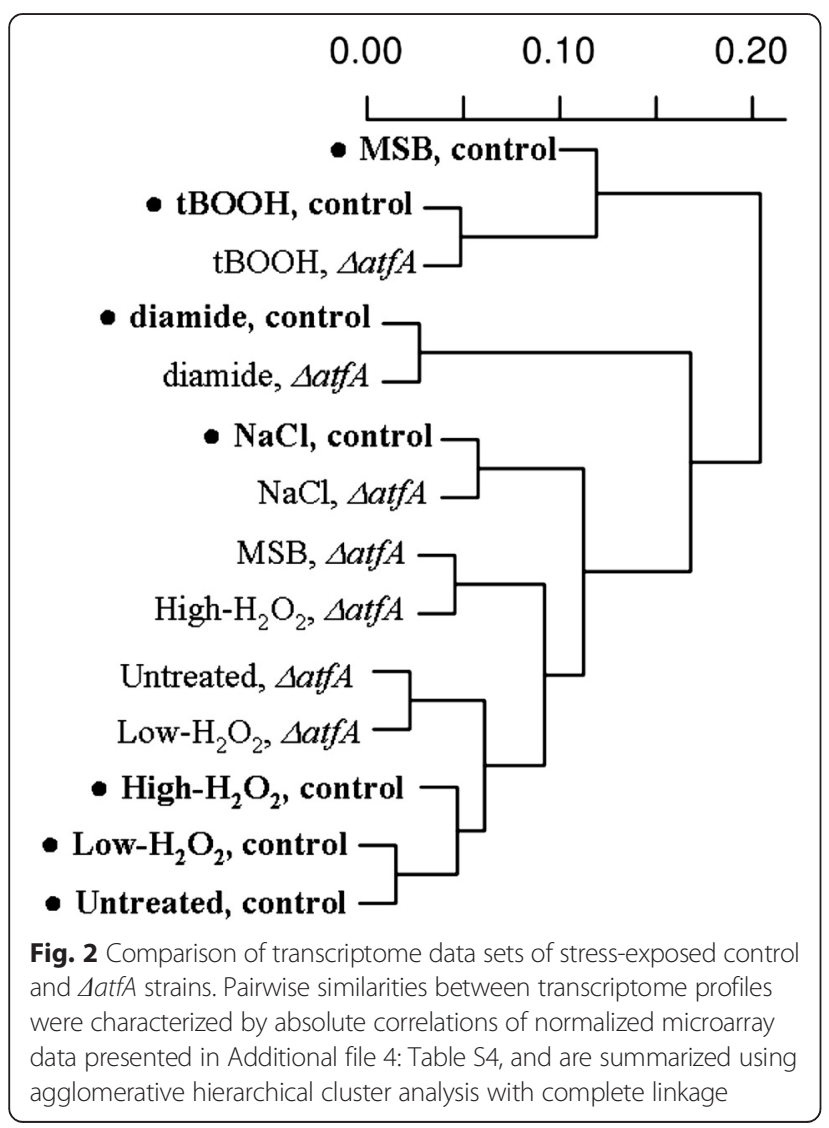

(MSB, h- $\mathrm{H}_{2} \mathrm{O}_{2}$, tBOOH) and "fatty acid catabolic process" $(\mathrm{tBOOH}$, diamide and $\mathrm{NaCl})$ for up-regulated genes under stress treatments indicated in parentheses (data not shown). Cross-stress adaptation experiments demonstrated that pre-treatments of the cultures with low concentrations of $\mathrm{H}_{2} \mathrm{O}_{2}$ or diamide decreased the growth inhibitory effects of MSB and pre-treatments with a low concentration of MSB decreased the growth inhibitory effect of $\mathrm{NaCl}$ in both the control and the $\triangle a t f A$ strains (Fig. 3).

\section{Consequences of atf $\mathrm{A}$ gene deletion}

Deletion of atfA altered the transcriptome profile of $A$. nidulans under unstressed conditions (Fig. 2, Additional file 4: Table S4). In the untreated cultures, 657 genes showed up-regulation while 542 were down-regulated in comparison to the control strain (Table 5).

In the gene deletion mutant, GO terms related to secondary metabolism enriched significantly for up-regulated genes (Additional file 7: Table S7). The significant shared GO terms for down-regulated genes included the followings: „cell wall organization”, "conidiophore development”, "phosphorelay signal transduction system", "regulation of protein phosphorylation", "calcium ion transmembrane transport" as well as "response to stimulus". The latter GO term is used for the description of a group of genes coding for important elements of the stress response system including $\operatorname{cat} B, \operatorname{tr} x R, A N 1131$, encoding a putative cytosolic $\mathrm{Cu} / \mathrm{Zn}$ superoxide dismutase and $m s n A$, encoding a transcription factor involved in the regulation of oxidative and salt stress responses [64-66] (Additional file 7: Table S7).

Deletion of atfA also altered the transcription profile of a large group of genes under various stress conditions (Table 5). The lack of the AtfA transcription factor prevented or reduced markedly the induction or repression of many genes which were stress-responsive in the control strain (Table 5; see "only in control" genes). In this group of genes, only those were regarded as AtfA- 


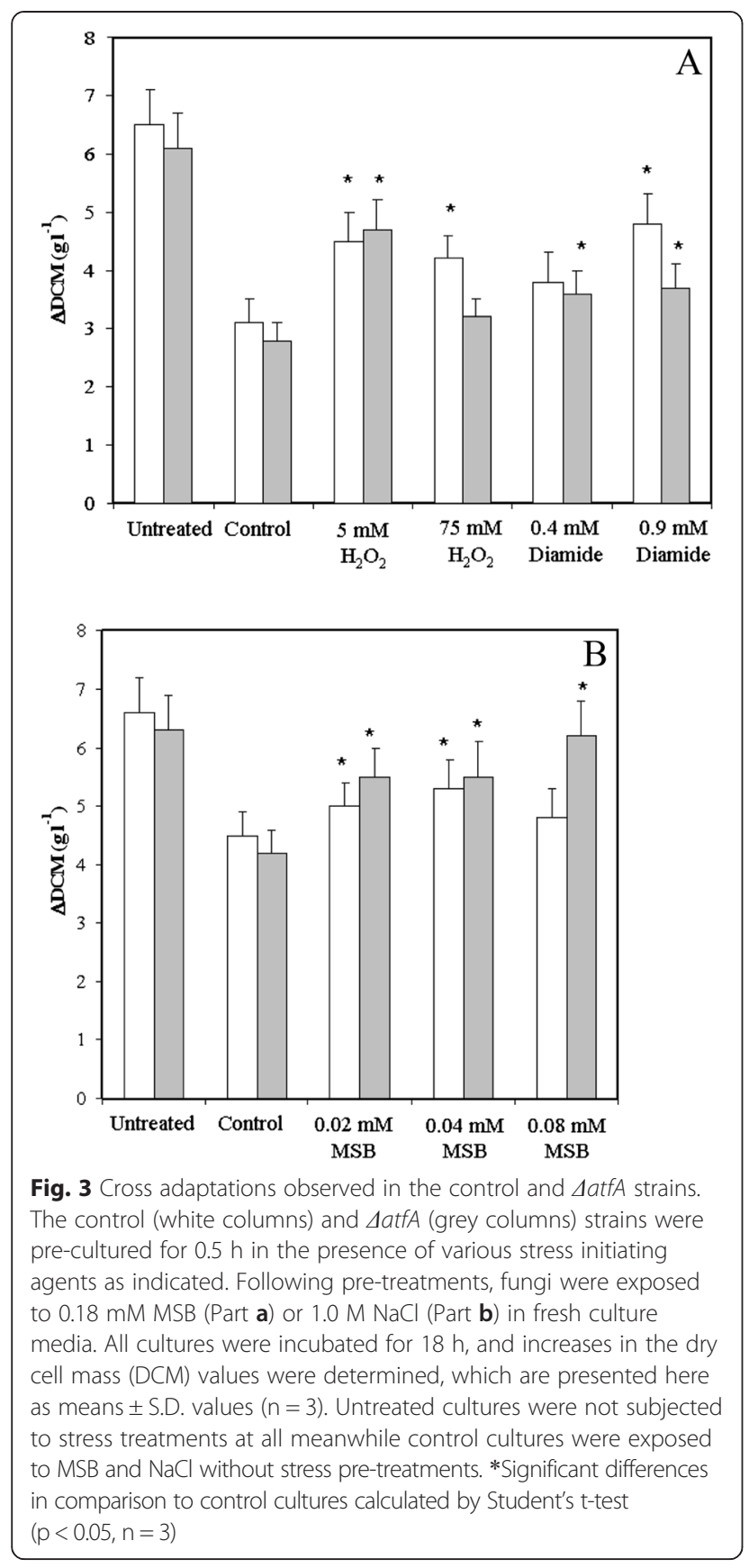

dependent where these transcriptional effects attributed to atfA deletion resulted in at least 2 -fold differences in the gene expression levels recorded in the control and gene deletion strains under stress treatments (Table 5; see the legend of "AtfA-dependent" genes either) The atfA gene deletion also resulted in up-regulation or down-regulation of certain genes which were not stress-responsive in the control strain (Table 5; see "only in $\triangle$ atfA" genes).

Deletion of atfA caused the largest size transcriptional changes in the MSB-treated cultures (Table 5, Fig. 2 and Additional file 4: Table S4). The ratio of AtfA-dependent, up-regulated genes and stress-responsive, up-regulated genes was also high in the case of $1-\mathrm{H}_{2} \mathrm{O}_{2}$ and $\mathrm{NaCl}$ treatments (Table 5). In contrast, atfA deletion affected only slightly the genome-wide transcriptional changes during diamide and $\mathrm{tBOOH}$ treatments (Table 5; Fig. 2 and Additional file 4: Table S4). In fact, the highest correlation between the transcriptome profiles of the $\triangle a t f A$ and control strains was found between the diamide treated cultures (Fig. 2, Additional file 4: Table S4).

The overlap between the groups of the AtfA-dependent genes found under various stress treatments was negligible. Importantly, among the COSR genes (Additional file 5: Table S5) only two were AtfA-dependent: AN7823, a gene in the sterigmatocystin gene cluster and encoding a putative peroxidase and AN9451, which is a functionunknown gene. Furthermore, there was no overlap between the significant shared GO terms recoded in the groups of AtfA-dependent genes under various stress conditions (data not shown).

\section{Secondary metabolism and stress}

Various stress conditions also influenced significantly the secondary metabolism of $A$. nidulans (Table 6, Additional files 8 and 9: Tables S8, S9). Among the 155 secondary metabolite biosynthesis genes up-regulated in the control strain 29 genes encoded transcription factors, nonribosomal peptide synthases, polyketide synthases or prenyltransferases, which were designated as "key genes" in further analyses. In many cases, only one or two genes showed significant transcriptional changes within one gene cluster. Therefore, only a cluster where more than half of its genes including at least one of its "key genes" were up-regulated was regarded as an up-regulated cluster. Altogether 5 clusters (clusters AN7884, AN6236, AN1680, AN10486 as well as the derivative of the benzaldehyde and F9775 hybrid cluster 2) showed up-regulation in the control strain at least in one stress treatment (Additional files 8 and 9: Tables S8 and S9). It is notable, that the numbers of down-regulated and up-regulated secondary metabolite biosynthetic genes, secondary metabolism key genes and secondary metabolite gene clusters were comparable (Table 6). The clusters with stressdependent down-regulation included the emericellamide cluster, clusters AN2924, AN8209 and AN7838 (AN12331), the microperfuranone cluster, the AN6236 cluster as well as the "no PKS/NRPS backbone 4" cluster (Additional files 8 and 9: Tables S8 and S9).

Deletion of atfA increased significantly the number of stress-inducible secondary metabolite biosynthetic genes and "key genes" under $1-\mathrm{H}_{2} \mathrm{O}_{2}$ and $h-\mathrm{H}_{2} \mathrm{O}_{2}$ exposures meanwhile decreased significantly the number of such stress-responsive genes in the case of diamide and $t \mathrm{BOOH}$ stress (Table 6, Additional files 8 and 9: Tables S8, S9). It is noteworthy that three secondary metabolite 
Table 5 Effect of atfA deletion on the transcriptome under different stress conditions

\begin{tabular}{|c|c|c|c|c|c|c|c|}
\hline & \multicolumn{7}{|c|}{ Stress exposures ${ }^{a}$} \\
\hline & None & MSB & $\mathrm{I}-\mathrm{H}_{2} \mathrm{O}_{2}$ & h- $\mathrm{H}_{2} \mathrm{O}_{2}$ & $\mathrm{tBOOH}$ & Diamide & $\mathrm{NaCl}$ \\
\hline & \multicolumn{7}{|c|}{ Number of genes influenced by stress exposure and/or atfA deletion } \\
\hline \multicolumn{8}{|l|}{ Increased transcription } \\
\hline Only in control ${ }^{\mathrm{b}}$ & - & 1053 & 117 & 444 & 391 & 497 & 709 \\
\hline Only in $\triangle a t f A^{c}$ & - & 480 & 318 & 508 & 927 & 387 & 386 \\
\hline In both strains ${ }^{d}$ & - & 521 & 36 & 355 & 975 & 1380 & 388 \\
\hline Control vs. $\Delta a t f A^{e}$ & 657 & 1646 & 649 & 585 & 709 & 526 & 725 \\
\hline AtfA-dependent ${ }^{f}$ & 657 & 721 & 64 & 130 & 148 & 60 & 313 \\
\hline Ratio of AtfA-dependent genes ${ }^{g}$ & & 0.46 & 0.42 & 0.16 & 0.11 & 0.03 & 0.29 \\
\hline \multicolumn{8}{|l|}{ Decreased transcription } \\
\hline Only in control ${ }^{\text {h }}$ & - & 1228 & 189 & 467 & 395 & 696 & 653 \\
\hline Only in $\triangle a t f A^{i}$ & - & 582 & 201 & 513 & 738 & 519 & 466 \\
\hline In both strains ${ }^{j}$ & - & 468 & 128 & 322 & 1046 & 1326 & 379 \\
\hline Control vs. $\Delta a t f A^{k}$ & 542 & 1815 & 648 & 661 & 749 & 310 & 431 \\
\hline AtfA-dependent' & 542 & 857 & 34 & 74 & 91 & 64 & 119 \\
\hline Ratio of AtfA-dependent genes & & 0.51 & 0.11 & 0.09 & 0.06 & 0.03 & 0.12 \\
\hline
\end{tabular}

${ }^{\mathrm{a}}$ Stressor concentrations are presented in footnotes to Table 2

${ }^{b}$ Up-regulation was defined by the threshold of $\log _{2}\left(I_{\text {treated, control }} / l_{\text {untreated, control }}\right)>1$ and $\log _{2}\left(I_{\text {treated, }} \Delta\right.$ atf $\left.A / l_{\text {untreated, } \Delta a t f A}\right) \leq 1$

'Up-regulation was defined by the threshold of $\log _{2}\left(I_{\text {treated, }} \Delta a t f A / l_{\text {untreated, } \Delta a t f A}\right)>1$ and $\log _{2}\left(I_{\text {treated, control }} / I_{\text {untreated, control }}\right) \leq 1$

dUp-regulation was defined by the threshold of $\log _{2}\left(I_{\text {treated, control }} / I_{\text {untreated, control }}\right)>1$ and $\log _{2}\left(I_{\text {treated, }}, \Delta a t f A / I_{\text {untreated, } \Delta a t f A}\right)>1$

eUp-regulation was defined by the threshold of $\log _{2}\left(I_{\text {treated, control }} / I_{\text {treated, }} \Delta a t f A\right)>1$

fUp-regulation was defined by the threshold of $\log _{2}\left(I_{\text {treated, control }} / I_{\text {treated, } \Delta a t f A}\right)>1, \log _{2}\left(I_{\text {treated, control }} / l_{\text {untreated, control }}\right)>1$ and $\log _{2}\left(I_{\text {treated, }} \Delta a t f A / l_{\text {untreated, }} \Delta a t f A\right) \leq 1$

${ }^{9}$ Number of AtfA dependent genes/number of genes regulated in the control strain

hDown-regulation was defined by the threshold of $\log _{2}\left(I_{\text {treated, control }} / I_{\text {untreated, control }}\right)<-1$ and $\log _{2}\left(I_{\text {treated, }} \Delta a t f A / l_{\text {untreated, } \Delta a t f A}\right) \geq-1$

'Down-regulation was defined by the threshold of $\log _{2}\left(I_{\text {treated, }} \Delta a t f A / l_{\text {untreated, } \Delta a t f A}\right)<-1$ and $\log _{2}\left(I_{\text {treated, control }} / l_{\text {untreated, control }}\right) \geq-1$

jDown-regulation was defined by the threshold of $\log _{2}\left(I_{\text {treated, control }} / l_{\text {untreated, control }}\right)<-1$ and $\log _{2}\left(I_{\text {treated, }}, \Delta a t f A / l_{\text {untreated, } \Delta a t f A}\right)<-1$

${ }^{k}$ Down-regulation was defined by the threshold of $\log _{2}\left(I_{\text {treated, control }} / I_{\text {treated, }} \Delta a t f A\right)<-1$

'Down-regulation was defined by the threshold of $\log _{2}\left(I_{\text {treated, control }} / I_{\text {treated, } \Delta a t f A}\right)<-1, \log _{2}\left(I_{\text {treated, control }} / I_{\text {untreated, control }}\right)<-1$ and $\log _{2}\left(I_{\text {treated, }} \Delta a t f A / I_{\text {untreated, } \Delta a t f A}\right) \geq-1$

gene clusters, namely the monodictyphenone cluster, the derivative of the benzaldehyde and F9775 hybrid cluster 1 and the pkf cluster were up-regulated in the $\Delta a t f A$ mutant in comparison to the control strain even under unstressed conditions and were also up-regulated under l- $\mathrm{H}_{2} \mathrm{O}_{2}$ and/or h- $\mathrm{H}_{2} \mathrm{O}_{2}$ exposures and were down-regulated when the gene deletion strain was exposed to diamide (not in the case of the monodictyphenone cluster), $t \mathrm{BOOH}$ or $\mathrm{NaCl}$ stress (Additional files 8 and 9: Tables $\mathrm{S} 8$ and S9). Up-regulation of pkeA (encoding the polyketide synthase of the benzaldehyde and F9775 hybrid cluster 1), $p k f A$ (encoding the polyketide synthase of pkf cluster) and $m d p G$ (encoding the polyketide synthase of the monodictyphenone cluster) in the $\triangle a t f A$ mutant in comparison to the control strain under unstressed conditions and under h$\mathrm{H}_{2} \mathrm{O}_{2}$ exposures, as well as down-regulation of $p k e A$ and $p k f A \mathrm{n}$ the mutant strain under $\mathrm{tBOOH}$ and diamide stress were validated by qRT-PCR experiments (Additional file 1 : Table S1).

\section{Discussion}

Oxidative and salt stress induced genome-wide transcriptional changes in $A$. nidulans, which were highly depended on the type and strength of the stress (Tables 3 and 4, Fig. 2). The observed global stress responses were similar to those found by other researchers earlier. For example, cell division-related processes, which are decisively important in the maintenance of vegetative growth and which influence replication, transcription, translation and cytoskeleton functions as well as sterol metabolism were inhibited under severe stress conditions in this study (Additional file 6: Table S6) as well as in other previous studies and in other fungi $[7,8,36,67,68]$. Up-regulation of catalase and peroxidase genes, furthermore genes coding for elements of glutathione, thioredoxin and trehalose metabolisms as well as for heat shock proteins and parts of DNA repair (Additional file 1: Table S1) have also been observed by other researchers in various fungal species $[7,8,36,69,70]$.

On the other hand, only weak correlation was found between the current gene expression data sets and the data coming from our earlier transcriptome [36] and proteome [62] studies. Besides of the variations in the culture and stress conditions applied in these works, the weak correlation can be clearly explained by several other important differences between the stress conditions employed. In the recent study, we used a whole- 
Table 6 Stress dependent regulation of secondary metabolite genes and clusters

\begin{tabular}{|c|c|c|c|c|c|c|c|c|}
\hline & \multicolumn{8}{|c|}{ Stress exposures ${ }^{a}$} \\
\hline & None & MSB & $\mathrm{L}-\mathrm{H}_{2} \mathrm{O}_{2}$ & $\mathrm{H}-\mathrm{H}_{2} \mathrm{O}_{2}$ & $\mathrm{tBOOH}$ & Diamide & $\mathrm{NaCl}$ & All \\
\hline \multicolumn{9}{|c|}{ THS30.3 control strain } \\
\hline \multicolumn{9}{|c|}{ Up-regulation } \\
\hline Key genes ${ }^{\mathrm{b}}$ & - & 11 & $2^{* *}$ & 5 & 16 & 16 & 4 & 29 \\
\hline All genes ${ }^{c}$ & - & 65 & $17^{* *}$ & $25^{* *}$ & 65 & 71 & $34^{* *}$ & 155 \\
\hline Clusters $^{d}$ & - & 2 & 0 & 0 & 3 & 1 & 0 & 5 \\
\hline \multicolumn{9}{|c|}{ Down-regulation } \\
\hline Key genes & - & 11 & 3 & 8 & 8 & 8 & 9 & 19 \\
\hline All genes & - & 46 & 22 & 37 & $38^{* * *}$ & 52 & 39 & 112 \\
\hline Clusters & - & 5 & 1 & 0 & 1 & 3 & 2 & 7 \\
\hline \multicolumn{9}{|c|}{ TNJ 92.4 $\Delta a t f A$ strain } \\
\hline \multicolumn{9}{|c|}{ Up-regulation } \\
\hline Key genes & - & 16 & $15^{*}$ & $16^{*}$ & 11 & 11 & 1 & 42 \\
\hline All genes & - & 53 & $48^{*}$ & $68^{*}$ & 60 & 54 & 29 & 179 \\
\hline Clusters & - & 2 & 3 & 2 & 2 & 0 & 0 & 7 \\
\hline \multicolumn{9}{|c|}{ Down-regulation } \\
\hline Key genes & - & $5^{* * *}$ & $3^{* * *}$ & $5^{* * *}$ & $19^{*}$ & $20^{*}$ & $17^{* * *}$ & 31 \\
\hline All genes & - & $16^{*, * * *}$ & $22^{* * *}$ & $26^{* * *}$ & $71^{*}$ & $82^{*}$ & $70^{*, * * *}$ & 139 \\
\hline Clusters & - & 0 & 1 & 2 & 5 & $7^{* * *}$ & 5 & 9 \\
\hline \multicolumn{9}{|c|}{ TNJ 92.4 ( $\triangle a$ atfA) vs. THS30.3 (control) } \\
\hline \multicolumn{9}{|c|}{ Up-regulation } \\
\hline Key genes & 11 & & & & & & & \\
\hline All genes & 43 & & & & & & & \\
\hline Clusters & 4 & & & & & & & \\
\hline \multicolumn{9}{|c|}{ Down-regulation } \\
\hline Key genes & 5 & & & & & & & \\
\hline All genes & $22^{* * *}$ & & & & & & & \\
\hline Clusters & 0 & & & & & & & \\
\hline
\end{tabular}

*Significant difference between the THS30.3 control and TNJ $92.4(\triangle a t f A)$ strain according to the Fisher's exact test $\left(p<0.05 ; n_{\text {key genes }}=94, n_{\text {all }}\right.$ genes $=467$, $\mathrm{n}_{\text {clusters }}=66$ )

* Significant difference in comparison to MSB, tBOOH and diamide treatment as well (in the same row) according to the Fisher's exact test ( $\mathrm{p}<0.05$;

$\mathrm{n}_{\text {key genes }}=94, \mathrm{n}_{\text {all genes }}=467, \mathrm{n}_{\text {clusters }}=66$ )

***Significant difference between the up- and down-regulated genes according to the Fisher's exact test $\left(p<0.05 ; n_{\text {key genes }}=94, n_{\text {all }}\right.$ genes $\left.=467, n_{\text {clusters }}=66\right)$

${ }^{\text {a }}$ Stressor concentrations are presented in footnotes to Table 2

${ }^{b}$ Key genes were defined as secondary metabolite cluster genes encoding transcription factors, non-ribosomal peptide synthases, polyketide synthases, terpene synthase or prenyltransferases according to Inglis et al. [114]

'Only genes of clusters determined either manually or experimentally were involved in the analysis [114]

${ }^{\mathrm{d} C l u s t e r s ~ w e r e ~ r e g a r d e d ~ a s ~ u p-r e g u l a t e d ~(o r ~ d o w n-r e g u l a t e d) ~ c l u s t e r ~ i f ~ a t ~ l e a s t ~ o n e ~ o f ~ i t s ~ k e y ~ g e n e s ~ a n d ~ m o r e ~ t h a n ~ h a l f ~ o f ~ i t s ~ m a n u a l l y ~ o r ~ e x p e r i m e n t a l l y ~ d e t e r m i n e d ~}$ genes were up-regulated (down-regulated)

genome-based DNA chip with 60-mer oligonucleotide probes designed to reduce cross-hybridizations between probes. In previous experiments by Pócsi et al. [36], an expressed sequence tag based DNA was applied, and in this case, potential cross-hybridization between paralogue genes can be a serious problem [71]. It is also worth mentioning that the FGSC26 strain used in our previous study, in contrast to strains used recently, harbored biA1 (biotin auxotrophy) and veA1 mutations [36]. Recent studies demonstrated that $\mathrm{VeA}$ is important in the regulation of oxidative stress response in several fungi including A. flavus [72], Cochliobolus heterostrophus [73] and Botrytis cinerea [74]. Moreover, nutritional supplements, e.g. riboflavin, paba, pyridoxine, can also have an impact on the observed stress sensitivity of the strains tested [48]. Although biotin did not affect significantly the growth of $A$. nidulans [48] the presence of this supplement in the medium may have influenced the stress response at the 
level of transcriptome. Poor correlation is a common problem when proteome and transcriptome data are compared, and the majority of the differences can be explained with divergent post-transcriptional and posttranslational regulations [75]. Considering all these variations in the experimental arrangements, it is remarkable that certain genes, notably AN2846 ( $g p x A)$ encoding a putative glutathione peroxidase and AN3581 (trxR) coding for thioredoxin reductase [76], still showed steady upregulation independently of the applied strains and methods (Additional files 2 and 3: Tables S2 and S3). Up-regulation of these genes seems to be crucial during MSB induced stress, which demonstrates the paramount importance of both the glutathione-based and the thioredoxin-based elements of the oxidative stress defense system in A. nidulans $[36,76,77]$.

\section{Environmental Stress Response (ESR) and COSR}

ESR was first defined in the budding yeast Saccharomyces cerevisiae as a sum of stereotypical changes observable in the transcription of more than 900 genes in response to very different types of stress $[15,78]$. In their study, Gasch et al. [15] found approximately 300 genes up-regulated and 600 genes down-regulated in more than 20 different stresses in baker's yeast. Later, Chen et al. [16] studied global gene expression changes under five stress conditions (heat, $\mathrm{H}_{2} \mathrm{O}_{2}, \mathrm{Cd}^{2+}$, sorbitol and methylmethane sulfonate stress) in the fission yeast Schizosaccharomyces pombe, and demonstrated that approximately 140 genes showed more than two-fold increases in their transcription in at least four stresses and approximately 100 genes showed more than two-fold decreases in their expression in at least three stresses [16]. Importantly, the number of stress specific genes induced by only one stressor was less than 100 in each case [16]. In the present study, the number of co-regulated genes (merely 7 genes co-induced and 6 genes co-repressed under all the five oxidative stress conditions as well as under $\mathrm{NaCl}$ exposures, and when $1-\mathrm{H}_{2} \mathrm{O}_{2}$ treatments were omitted from analyses $51+65$ genes showed coregulation (Table 3). Meanwhile the number of coregulated genes was small the number of genes regulated exclusively by one certain type of stress was well above 1000 (Table 3). These observations together with the sharply decreasing number of co-regulated genes as a function of the number of stress initiating agents studied (Table 3) does not support the existence of a S. cerevisiae-type ESR in $A$. nidulans.

We assume that the observed co-regulations were most likely consequences of the overlapping physiological effects of the stressors especially in the case of severe stress treatments and not of the existence of a general ESR. Severe stress causes aspecific damages in versatile biomolecules like proteins, nucleic acids and lipids, decreases the ATP/AMP ratio or influences the redox balance and ion homeostasis independently of the way of the initiation of stress. Such non-specific physiological changes may be reflected, at least to some extent, in the stress-initiated alterations in the transcriptome profiles.

On the other hand, comparing stress treatments similar in type and strength can be a useful and beneficial strategy to identify a group of genes co-regulated by the same stress sensing and signaling pathways. COSR gene groups were constructed by identifying and collecting co-regulated genes through mapping the global transcriptional changes recorded under three "severe" oxidative stress conditions elicited by MSB, $t \mathrm{BOOH}$ and diamide treatments (Additional file 5: Table S5). Based on this experimental arrangement, COSR genes were found in great number (873 genes) and, similarly to the ESR genes in S. cerevisiae [15, 78], the function of the up-regulated genes was very diverse with no significant shared GO term identified meanwhile the majority of the down-regulated genes was related to the maintenance of vegetative growth, e.g. replication, cytoskeleton functions as well as nuclear and cell divisions. Further studies are needed to identify the stress signaling and regulatory pathways governing the expression of the COSR genes. It is noteworthy that two bZIP-type transcription factors, NapA and RsmA, are transcriptionally regulated within the frame of COSR in A. nidulans (Additional files 1 and 5: Tables S1 and S5), which suggests the importance of both the maintenance of the redox homeostasis of the cells and the production of secondary metabolites $[50,63]$ as an inseparable part of the oxidative stress defense.

The characteristics of ESRs observed in various fungi are summarized in Table 7. Unfortunately, the experimental design (e.g. the type, the strength and the number of the tested stresses as well as the criteria used to define stereotypical changes) was different in these experiments, which is a limitation when we compare the data. However, Table 7 suggests that ESR may be limited only to the budding yeast $S$. cerevisiae and to its close relatives like C. glabrata, where Msn2/4 transcription factors evolved to regulate stress responses under a wide spectrum of environmental stress. It is noteworthy that Msn2/4 regulate numerous, but not all, genes upregulated in ESR, and these transcription factors are probably not involved in down-regulations [15]. Roetzer et al. [18] found only limited overlap (268 genes) between the ESRs of S. cerevisiae and C. glabrata, and this overlap is even smaller when other species are considered $[16,17]$. These data question the existence of a universal stress-response set of genes in fungi, the induction of which were equally beneficial in all fungal species and in all ecological niches they occupy. Fungi seem to choose 
Table 7 Properties of ESR in different fungi

\begin{tabular}{lllll}
\hline Species & Number of genes ${ }^{\text {a }}$ & $\begin{array}{l}\text { Number of genes showing stereotypical } \\
\text { behavior in different stresses }\end{array}$ & Regulator of ESR & Reference \\
\hline Saccharomyces cerevisiae & $5907\left(\mathrm{WGD}^{\mathrm{b}}\right)$ & 868 & Msn2/4 & Msn2/4 \\
Candida glabrata & $5214(\mathrm{WGD})$ & 752 & Sty 1 & {$[15]$} \\
Schizosaccharomyces pombe & 5123 & 140 & Hog 1 & {$[16]$} \\
Candida albicans & 6219 & 61 & $?$ & {$[17]$} \\
Aspergillus nidulans & 10678 & 116 & This study
\end{tabular}

The numbers of protein encoding genes were originated from the following web pages: http://www.ncbi.nlm.nih.gov, http://www.pombase.org, http://www.candidagenome.org, http://www.aspgd.org

${ }^{b}$ WGD: whole genome duplication

one of two options, evolving a set of 'unique' stress responses or, instead, a 'general' stress response. A set of stress-specific "unique" stress responses can provide the fungus with an appropriate adaptation to a wide array of stress but need numerous genes and a complex and robust signaling network to regulate them like that described in the a Aspergilli $[9,48,79,80]$. On the other hand, a general stress response can be operated well even with less genes and with a less complex signaling network and can provide the fungi like saccharomycetous yeasts with a perhaps less sophisticated but instantaneous stress response even to cope with impending stress [12, 13]. Importantly, the number of S. cerevisiae genes is approximately half of that of the Aspergilli, which indicates that the type of stress response ("unique" vs. "general") is likely also dependent on the size of the fungal genome (Table 7).

A wide spectrum of genetic evidence demonstrates that overexpression of even a single gene can increase the stress tolerance $[81,82]$ and, therefore, if this gene is part of ESR its up-regulation by one stress can cause adaptation to another stress $[16,78]$. This explanation is commonly used to explain cross-stress adaptation phenomena and the physiological significance of ESR. Cross-stress adaptation was also observed in both the control and the $\triangle a t f A$ strains in our experiments (Fig. 3). The most interesting cross-stress adaptation was developed with $\mathrm{H}_{2} \mathrm{O}_{2}$ when employed at $5 \mathrm{mM}$ concentration, which alone caused only small transcriptional changes in $A$. nidulans and these alterations in gene expressions were quite different from those caused by MSB (Fig. 2; only 81 up-regulated and 24 down-regulated genes overlapped). Importantly, $1-\mathrm{H}_{2} \mathrm{O}_{2}$ exposures did not elicit even two-fold increases in the transcriptions of genes encoding basically important elements of MSB stress response, including FeS cluster assembly and DNA repair proteins, trehalose, glutathione or thioredoxin metabolic and antioxidant enzymes as well as heat shock proteins and metallo-chaperones (data not shown). However, using $5 \mathrm{mM} \mathrm{H}_{2} \mathrm{O}_{2}$ in stress pre-treatments resulted in clear-cut adaptation to severe MSB stress (Fig. 3). In accordance with these observations, Berry et al. [13] were able to induce $\mathrm{H}_{2} \mathrm{O}_{2}$ tolerance in $S$. cerevisiae by preexposing baker's yeast cultures to mild $\mathrm{NaCl}$, dithiotreitol or heat stress although there were only little overlaps in the lists of genes induced by different pre-treatments. In another study, Guan et al. [83] found that Ctt1 catalase produced under $\mathrm{NaCl}$ pre-treatment was distributed to daughter cells during subsequent divisions and was responsible for the elevated $\mathrm{H}_{2} \mathrm{O}_{2}$ tolerance of $S$. cerevisiae cells. They also demonstrated that stress pre-treatments caused a faster response in gene expression during subsequent high-dose stress treatments, which required the nuclear pore component protein Nup42 [83]. Furthermore, several studies have demonstrated the overlapping nature of stress signaling pathways with numerous interplays, cooperations and even cross-talks between them $[8,79,80]$. The regulation of this complex and robust network is based on protein-protein interactions and/or modifications rather than on transcriptional changes alone. A possible explanation for cross-stress adaptation therefore is that various pre-treatments can activate the signaling network, which increases subsequently the efficiency of sensing of and/or responding to versatile types of environmental stress. It is possible that changes in the expressions of stress response genes during pre-treatments contribute to the adaptation to impending, more severe environmental stress. However, we suggest that transcriptional up-regulations of stress response genes under pre-treatments are not essential to reach cross-stress adaptations in A. nidulans.

\section{Involvement of AtfA in the regulation of stress response in $A$. nidulans}

Atf1 is a bZIP-type transcription factor regulated by the Sty1 MAPK pathway in S. pombe and is responsible for regulation of genes involved in various stress responses including heat, oxidative, reductive, osmotic and starvation stress [84]. Atf1 can form heterodimer with another bZIP-type transcription factor, Pcr1 and some of the target genes are regulated by this hetrodimer [85]. In $A$. nidulans, the Atf1 orthologue AtfA is regulated by the HogA/SakA MAPK pathway [49]. The phenotypes of the 
$\triangle a t f A$ gene deletion strains demonstrate that AtfA is necessary for normal vegetative growth and sporulation as well as for oxidative and heat stress tolerance in $A$. nidulans [46-49] (Fig. 1, Table 1). In the present study, the deletion of atfA affected the transcription of an unexpectedly high number of genes under MSB stress (Fig. 2, Table 5). In contrast, the transcriptome profiles of the $\triangle a t f A$ mutant and the control strains were more similar during $\mathrm{H}_{2} \mathrm{O}_{2}, t \mathrm{BOOH}, \mathrm{NaCl}$ and especially under diamide treatments (Fig. 2, Table 5). Moreover, the lack of atf $A$ also affected the transcription of several genes under unstressed conditions. Deletion of atf1 in S. pombe also caused inductions and repressions of several genes even in unstressed cultures and also prevented the induction of numerous genes under stress treatments [16].

The stress-dose dependent activation of Atf1 is also well described in S. pombe. Atf1 regulates the oxidative stress response in high dose $\mathrm{H}_{2} \mathrm{O}_{2}$ treatments while its importance is less significant when fission yeast was exposed to low $\mathrm{H}_{2} \mathrm{O}_{2}$ concentrations when the Pap1 transcription factor played a key role [86]. In A. nidulans, the ratio of AtfA-dependent genes was much higher in l- $\mathrm{H}_{2} \mathrm{O}_{2}(5 \mathrm{mM})$ elicited stress than in $\mathrm{h}-\mathrm{H}_{2} \mathrm{O}_{2}(75 \mathrm{mM})$ triggered stress (Table 5). However the overlap between the two stress responses was significantly less in the $\triangle a t f A$ mutant than in the control strain (Table 4). These observations suggest that the majority of AtfAdependent genes in $1-\mathrm{H}_{2} \mathrm{O}_{2}$ stress were also part of the h- $\mathrm{H}_{2} \mathrm{O}_{2}$ stress response. In fact, 77 out of the 98 AtfAdependent genes recorded in $1-\mathrm{H}_{2} \mathrm{O}_{2}$ stress also showed stress responsive regulation under $h-\mathrm{H}_{2} \mathrm{O}_{2}$ exposures. Therefore, the low ratio of the AtfA-dependent genes during $h-\mathrm{H}_{2} \mathrm{O}_{2}$ elicited stress was not the consequence of the decreased number of AtfA-dependent genes but could be attributed to the increased number of AtfAindependent genes instead.

One of the main differences between the regulations of the oxidative stress responses in A. nidulans and $S$. pombe is that the number of genes likely under AtfA control was more stress-type-dependent in $A$. nidulans than in S. pombe (Table 5). Several genes showing AtfAdependent regulation in one stress treatment did not show any AtfA-dependency under another stress condition in our experiments. It is remarkable that even in the group of the COSR genes merely two showed an AtfA-dependent regulatory pattern (Additional file 5: Table S5).

Several GO terms related to stress signaling and regulation ("phosphorelay signal transduction system", "regulation of protein phosphorylation", "calcium ion trans membrane transport" as well as "response to stimulus") were typical of the group of down-regulated genes in the $\triangle a t f A$ mutant under unstressed conditions (Additional file 7: Table S7). According to this, we hypothesize that
AtfA coordinates the up-regulation of certain regulatory genes (e.g. members of the phosphorelay signal transduction system; Additional file 7: Table S7) under environmental stress and also determined their basal transcription levels under unstressed conditions. Decreases in the expressions of these genes in the gene deletion mutant grown in unstressed cultures disturbed the homeostasis of the strain, resulted in alterations in the transcription patterns of a large number of other genes (Fig. 2, Table 5, Additional file 7: Table S7).

Due to the networking nature of signaling pathway, the missing AtfA was compensated by other regulatory proteins under $\mathrm{H}_{2} \mathrm{O}_{2}, \mathrm{tBOOH}$, diamide, $\mathrm{NaCl}$, which resulted in global transcriptional profiles very similar to those recorded for the control strain (Fig. 2, Table 5). Considering a most recently published study of Bok et al. [50] the transcription factor NapA (orthologue of $S$. pombe Pap1 [86]), another bZIP-type oxidative stress response regulator, can be a candidate which may take over AtfA functions under hydrogen peroxide induced oxidative stress. NapA, which is under RsrA control, seems to be the master regulator of the specific response to peroxide stress [50].

When cells were exposed to MSB the signaling network was unable to substitute AtfA satisfactorily, which resulted in serious disturbances in the cell homeostasis and concurrently altered the transcription levels of a large group of genes, which were therefore described as potential AtfA targets (Fig. 2, Table 5). Further research is needed to identify which genes among the AtfA target genes responsible for the efficient stress response under MSB stress treatment.

\section{Secondary metabolism and stress response}

Emerging data demonstrate that there are interplays between the regulations of oxidative stress response and secondary metabolism in fungi. Induction of secondary metabolite production by oxidative stress and its inhibition by antioxidants have been observed in several species, and even transcription factors affecting both secondary metabolism and oxidative stress response have been identified [42-44, 63, 66, 87-90]. Our transcriptome data also support the importance of stress in the regulation of secondary metabolism because all stressors including $\mathrm{NaCl}$ affected significantly the transcription of secondary metabolite biosynthesis genes (Table 6, Additional file 8: Table S8) under experimental conditions like culturing at $37{ }^{\circ} \mathrm{C}$ in glucose containing minimal medium, which are generally not beneficial for secondary metabolite production in this species. Moreover, the $\triangle a t f A$ strain, in addition to being more sensitive to oxidative stress (Fig. 1), also had a more altered expression pattern of secondary metabolism genes under various stress treatments when compared to 
the control strain (Table 6, Additional files 8 and 9: Tables S8 and S9).

Both rsmA (AN4562) and napA (AN7513) was part of the COSR in the control strain (Addtional file 5: Table S5) which is in good accordance with increased number of up-regulated secondary metabolit genes a secondary metabolit key genes under MSB, $t \mathrm{BOOH}$ and diamide stress in comparison to the other stress applied (Table 6). It supports the view that RsmA and NapA can be a link between the regulation of stress response and secondary metabolite production in $A$. nidulans [43, 63, 89].

Cryptic secondary metabolite gene clusters are in the center of industrial investigations since they may be exploitable in the production of novel secondary metabolites. In addition to the overexpression of the complete gene cluster in a suitable organism [91], the overexpression of a cluster-specific transcription factor or, alternatively, a global regulator of secondary metabolism, e.g. LaeA, in the host organism [92, 93] are frequently used techniques to identify the products of cryptic gene clusters. Our study demonstrate that deletion of an oxidative stress response regulator gene in combination with mild oxidative stress can also be applicable to overproduce the products of certain gene clusters, which may lead to identification of new secondary metabolites (Additional file 9: Table S9).

It is worth noting that many known secondary metabolite gene clusters of $A$. nidulans were not stress responsive in our experiments (Additional files 9 and 10: Tables S9 and S10). Since we studied only the early global transcriptional changes further studies will address the question if the regulation of these clusters and genes are independent of environmental stress or the progression of the transcriptional changes will need more time. More importantly, environmental stress cannot only induce some secondary metabolite gene clusters but can also repress others (Table 6, Additional file 9: Table S9). Strategies based on the application of certain antioxidants to prevent the accumulation of ROS and, consequently, the formation of mycotoxins may efficiently inhibit the production of certain mycotoxins but, concomitantly, may also induce the formation of other unwanted secondary metabolites.

The ecological and/or physiological value of the redox regulation of secondary metabolite production is unclear. Reverberi et al. [42] suggested that production at least some the secondary metabolites (e.g. aflatoxins) contained several oxidative steps therefore their biosynthesis helped maintaining the redox status of the cells under oxidative stress. On the other hand, beside wellknown and well-characterized ROS productions observable during pathogen - host interactions, competing micro-organisms can also elicit oxidative stress either through the extracellular formation of $\mathrm{H}_{2} \mathrm{O}_{2}[94,95]$ or via do novo synthesis of secondary metabolites, which generate oxidative stress in sensitive organisms [96-98]. Such ecological role can be attributed for example to aflatoxin B1 produced by certain aspergilli [99]. Similarly, hyperosmotic stress is also frequently induced e.g. by ethanol producing microbes [100]. The "artificial" stressors used in research laboratories may imitate the attack of a competitive species or a host organism, which may explain the stress dependent regulation of secondary metabolite clusters. Other explanations, like the use of secondary metabolite spectra to inform other cells of the same species about the physiological status of a given cell cannot be ruled out either. Connections between secondary metabolite production and development as well as the importance of secondary metabolites or secondary metabolite-like compounds in the regulation and coordination of sporulation, germination or sexual development of a colony have been demonstrated by several researchers [101-103].

\section{Conclusions}

A. nidulans showed very stress-specific (in case of MSB stress highly AtfA-dependent) global transcriptional stress responses under the stress conditions tested in this study. The remarkable flexibility of the stress response system operating in A. nidulans, and probably in other aspergilli as well, explains the evolutionary success of this genus. This flexibility can be important for human pathogenic species, e.g. for A. fumigatus, to cope with the harsh and stressful environmental conditions present in the human body and, meanwhile, it can also set up challenges when we aim at the improvement of industrial strains. The stress-dependent regulation of secondary metabolite gene clusters is of paramount importance when cryptic secondary metabolites are identified and also when novel strategies to control the production of secondary metabolites including mycotoxins are considered and evaluated.

\section{Methods}

Strains, culture conditions, stress sensitivity tests and cross-stress adaptation experiments

In this study, A. nidulans TNJ 92.4 (pyrG89, AfupyrG ${ }^{+}$; pyroA4; $\triangle$ atfA::pyroA; $\left.v e A^{+}\right)$as a $\triangle$ atfA gene deletion strain and THS30.3 (pyrG89, AfupyrG $G^{+}$; $p y r o A^{+} ; v e A^{+}$) as the appropriate control strain were used. The atfA deletion $(\triangle a t f A)$ mutants were generated by double-joint PCR (DJ-PCR) as described [104]. The flanking regions of each atfA gene were amplified by PCR with primer pair, oNK968 (5'-AGTTGCGTCATCACGTTATTGGTG-3'), 974 (5'-ACTTCTGCAGTCGGAATTGGCCTGATGGGTGG CACACAACCATAGATC-3') (atfA5' with pyroA tail) and oNK-971 (5'-ACTACCTTTGATGAGTGCTGACTAG-3'), 975 (5'-TGGTGAGAACACATGCACAACTTGATCACT TGACTAACTGGCGCAACG-3') (atfA3' with pyroA tail) 
from the genomic DNA. The pyroA marker was amplified with the primer pair oNK-395 (5'-ATCTCATGGGTGC TGTGCGAAAGG-3'):oNK-396 (5'-TTGCATCGCATAG CATTGCATTGC-3'). The final deletion construct was amplified with the nested primer set oNK-972 (5'-TGCA GAGACTTCAAGAGTCAAGAG-3'):oNK-973 (5'-TACA CATCTGCCATGACATCTCTG-3') and was introduced into TNJ 36 (pyrG89, AfupyrG+; pyroA4; veA $A^{+}$) [105] using the Vinoflow FCE lysing enzyme (Novo Nordisk) [106]. For THS30.3, the partial wild type pyro $A^{+}$PCR fragment covering the pyroA4 mutation was amplified with the primer pair oHS656 (5'-GGACCCGAGAGGCGAGAGC TTA-3'):oHS657 (5'-GACACCATCACAGCCAAGCTGC$3^{\prime}$ ) from the genomic DNA and was introduced into TNJ 36. The strains were maintained on Barratt's nitrate minimal medium (NMM medium [107]), and NMM agar plates were incubated at $37^{\circ} \mathrm{C}$ for $6 \mathrm{~d}$ [63]. Conidia harvested from these 6-day-old plates were used in all further experiments.

The stress sensitivities of the strains were tested on NMM agar plates containing 0.03-0.24 mM MSB, 2$12 \mathrm{mM} \mathrm{H}_{2} \mathrm{O}_{2}, 0.2-1.2 \mathrm{mM} t \mathrm{BOOH}, 0.5-4 \mathrm{mM}$ diamide or $0.5-2 \mathrm{M} \mathrm{NaCl}$. Plates were spot-inoculated with $5 \mu \mathrm{l}$ freshly made conidia suspension $\left(10^{5}\right.$ conidia $\left.\mathrm{ml}^{-1}\right)$ and were incubated at $37{ }^{\circ} \mathrm{C}$ for $5 \mathrm{~d}$. Diameters of the colonies were measured and used for the characterization of the stress sensitivities of the strains [63].

To study genome-wide transcriptional changes, fungi were grown in shake flasks $(500 \mathrm{ml})$ containing $100 \mathrm{ml}$ Barratt's NMM broth. All submerged cultivations were carried out at $37{ }^{\circ} \mathrm{C}$ and at $3.7 \mathrm{~Hz}$ shaking frequency. Cultures were inoculated with $1 \times 10^{8}$ conidia and were incubated for $16 \mathrm{~h}$. Three parallel cultures of the control strain were mixed and than were divided into three equal, $100-100 \mathrm{ml}$, parts. In the case of the $\triangle a t f A$ strain, nine $16 \mathrm{~h}$ cultures were mixed, the mycelial pellets were let sink down and appr. $600 \mathrm{ml}$ supernatant was removed. The remaining $300 \mathrm{ml}$ cell suspension containing now the vegetative fungal tissue from nine cultures was divided into three equal, $100-100 \mathrm{ml}$, parts. As a result, the starting dry cell masses (DCMs) were always between 4-5 $\mathrm{g} \mathrm{l}^{-1}$ for both the mutant and the control strains. In stress exposure experiments, the cultures were treated with $0.12 \mathrm{mM}$ MSB, 5 and $75 \mathrm{mM} \mathrm{H}_{2} \mathrm{O}_{2}$, $0.8 \mathrm{mM} t \mathrm{BOOH}, 1.8 \mathrm{mM}$ diamide, $0.6 \mathrm{M} \mathrm{NaCl}$ or were kept untreated (control), and were further incubated for $0.5 \mathrm{~h}$. The growth inhibitory effects of the different stressors were estimated by measuring the reduction in the increase of DCM at $10 \mathrm{~h}$ after treatment according to Pusztahelyi et al. [108].

In cross-stress adaptation experiments, $16 \mathrm{~h}$ cultures were pre-treated with $0.02,0.04$ and $0.08 \mathrm{mM} \mathrm{MSB}, 5$ and $75 \mathrm{mM} \mathrm{H}_{2} \mathrm{O}_{2}, 0.4$ and $0.9 \mathrm{mM}$ diamide or were kept untreated (control), and were further incubated for $0.5 \mathrm{~h}$ as described above. After stress pre-treatments, mycelia were filtered out on sintered glass, were washed with freshly prepared NMM medium and were transferred immediately into fresh NMM medium also supplemented with $0.18 \mathrm{mM} \mathrm{MSB}$ or $1 \mathrm{M} \mathrm{NaCl}$. Increases in the DCMs were detected after cultivation for $18 \mathrm{~h}$.

\section{Quantitative real-time reverse-transcription polymerase chain reaction (qRT-PCR) assays}

Samples were always taken at $30 \mathrm{~min}$ after stress treatment. Total RNA was isolated from lyophilized mycelia coming from 4 parallel experiments following the instructions of Chomczynski [109]. qRT-PCR experiments were carried out as described earlier [110] with the primers and annealing temperatures presented in Additional file 10: Table S10. Primers were designed based on the locus sequences of $A$. nidulans FGSC A4 obtained from The Broad Institute's homepage (www.broadinstitute.org). Relative transcription levels were quantified with $\Delta \Delta \mathrm{CP}=\Delta \mathrm{CP}_{\text {treated }}-\Delta \mathrm{CP}_{\text {control }}$, where $\Delta \mathrm{CP}_{\text {treated }}=\mathrm{CP}_{\text {reference gene }}-\mathrm{CP}_{\text {tested gene }}$ measured from treated cultures or the cultures of the mutant strain, $\Delta \mathrm{CP}_{\text {control }}=\mathrm{CP}_{\text {reference gene }}-\mathrm{CP}_{\text {tested gene }}$ measured from untreated cultures or the wild type strain. $\mathrm{CP}$ values stand for the qRT-PCR cycle numbers of crossing points. The $a c t A$ gene (AN6542 [79]) was used as reference gene.

\section{Microarray analysis}

For DNS chip studies, Agilent 60-mer oligonucleotide high density arrays $4 \times 44 \mathrm{~K}$ (Kromat Ltd., Budapest, Hungary) were constructed. Oligos were designed with the eArray software of Agilent (design number 031140). Total RNA was isolated from lyophilized mycelia after $30 \mathrm{~min}$ after stress treatments as described above in qRT-PCR assays. Importantly, total RNA pools used in microarray and qRT-PCR analyses were isolated in independent experiments. For DNA chip studies, RNA samples gained from three parallel experiments were pooled in $1: 1: 1$ ratios.

Cyanine-3 (Cy3) labeled cRNA was prepared according to Agilent's One-Color Microarray-Based Gene Expression Analysis Low Input Quick Amp Labeling protocol, followed by RNeasy Mini spin column purification (QIAGEN). The quality of labeled cRNA was evaluated on the Agilent Bioanalyser 2100 and quantified using an ND-1000 NanoDrop spectrophotometer. Fragmented cRNA samples (1650 ng; specific activity $>20.0$ pmol

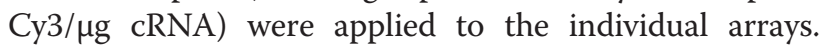
Slides were placed into a rotating Agilent hybridization oven and were hybridized at $65^{\circ} \mathrm{C}$ and $10 \mathrm{rpm}$ for $17 \mathrm{~h}$. After hybridization, microarrays were washed at room temperature with GE Wash Buffer 1 (Agilent) and at $37{ }^{\circ} \mathrm{C}$ GE Wash buffer 2 (Agilent), then dried by brief centrifugation. Slides were scanned immediately after 
washing on the Agilent DNA Microarray Scanner (FE SW 11.1) using one color scan setting for $1 \times 44 k$ array slides (Extended Dynamic Range, Scan Area $61 \times 21.6$ mm, Scan resolution $5 \mu \mathrm{m}$, Dye channel is set to Green and Green PMT is set to XDR Hi $100 \%$ and XDR Lo $10 \%$ ). Agilent's Feature Extraction software (version 11.1) was used to obtain prenormalised data. Prenormalised microarray data (median foreground, median background) was background corrected using the normexp + offset method suggested by Ritchie et al. [111] followed by quantile normalization between arrays [112] as in Smyth [113]. The full data set was deposited in the Gene Expression Omnibus (GEO; http://www.ncbi.nlm.nih.gov/geo/) with the following accession number: GSE63019.

Genes showing at least two-time-increase or decrease in their relative transcription levels were regarded as upregulated and down-regulated genes, respectively. Physiological function categories were created according to the GO annotation available at AspGD (http://www.aspergillusgenome.org) and at Broad Institute (http://www.broadinstitute.org). In the case of the secondary metabolite genes, cluster borders determined either manually or experimentally were used [114]. The GO Term Finder of Aspergillus Genome Database (http://www.aspergillusgenome.org) was used to find significant shared GO terms of those used to describe the genes in a selected list $(\mathrm{p}<0.1)$.

\section{Calculating similarities between transcriptome data sets}

Pairwise similarities between global transcription profiles were measured by absolute correlations of normalized microarray data and summarized using agglomerative hierarchical cluster analysis with complete linkage using the R 2.15.2 software [115].

\section{Additional files}

Additional file 1: Table S1. Transcriptional changes of selected genes measured with QRT-PCR.

Additional file 2: Table S2. Comparison of old and new transcriptome data sets.

Additional file 3: Table S3. Comparison of proteome and new transcriptome data sets.

Additional file 4: Table S4. Pairwise correlation coefficients of transcriptome data sets.

Additional file 5: Table S5. List of COSR genes.

Additional file 6: Table S6. List of significant shared GO terms for COSR genes.

Additional file 7: Table S7. List of AtfA dependent genes in untreated cultures as well as list of significant shared GO terms for them.

Additional file 8: Table S8. Up- and down-regulated secondary metabolite genes.

Additional file 9: Table S9. Stress dependent behavior of secondary metabolism gene clusters in A. nidulans.

Additional file 10: Table S10. Primer pairs used in this study.

\section{Abbreviations}

COSR: Core Oxidative Stress Response; DCM: Dry cell mass;

ESR: Environmental stress response; MSB: Menadione sodium bisulfite; NMM medium: Barratt's nitrate minimal medium; $\mathrm{tBOOH}$ : $t$-butylhydroperoxide.

\section{Competing interests}

The authors declare that they have no competing interests.

\section{Authors' contributions}

TE participated in designing and coordination of the study, evaluation of microarray data, and wrote the manuscript. VSz carried out the GRT-PCR experiments. EO carried out the cross resistance experiments and tested the phenotype of strains. KA carried out the normalization of microarray data and performed statistical analyses. HSP and KHH carried out the molecular genetics experiments. JHY participated in designing/coordination of the study and writing the manuscript. IP conceived the study, participated in the evaluation of microarray data and writing the manuscript. All authors read and approved the final manuscript.

\section{Acknowledgements}

The authors are indebted to Mrs. Gáborné Tóth, Ms Zsuzsa Szabó and Mr. Imre Pócsi for their valuable contributions. This work was supported by the Hungarian Scientific Research Fund (OTKA K100464, K112181) and by the SROP-4.2.2.B-15/1/KONV-2015-0001 project. The project has been supported by the European Union, co-financed by the European Social Fund. The work at UW-Madison was supported by USDA CSREES Hatch (WIS01195) and the Intelligent Synthetic Biology Center of Global Frontier Project (2011-0031955) funded by the Ministry of Education, Science and Technology grants to JHY. This work was partly supported by Basic Science Research Program through the National Research Foundation of Korea (NRF) funded by the Ministry of Education, Science and Technology (NRF-2014R1A1A2059103).

\section{Author details}

'Department of Biotechnology and Microbiology, Faculty of Science and Technology, University of Debrecen, P.O. Box 63, H-4032 Debrecen, Hungary. ${ }^{2}$ Department of Zoology, Faculty of Sciences, Eszterházy Károly College, Eszterházy út 1, H-3300 Eger, Hungary. ${ }^{3}$ Department of Bacteriology, University of Wisconsin, 1550 Linden Dr, Madison, WI 53706, USA.

${ }^{4}$ Department of Pharmaceutical Engineering, Woosuk University, 565-701 Wanju, Republic of Korea.

Received: 22 December 2014 Accepted: 15 June 2015

Published online: 27 June 2015

\section{References}

1. Kültz D. Molecular and evolutionary basis of the cellular stress response. Annu Rev Physiol. 2005;67:225-57.

2. Gasch AP. Comparative genomics of the environmental stress response in ascomycete fungi. Yeast. 2007;24:961-76.

3. Nikolaou E, Agrafioti I, Stumpf M, Quinn J, Stansfield I, Brown AJ. Phylogenetic diversity of stress signalling pathways in fungi. BMC Evol Biol. 2009:9:44.

4. Estruch F. Stress-controlled transcription factors, stress-induced genes and stress tolerance in budding yeast. FEMS Microbiol Rev. 2000;24:469-86.

5. Herrero E, Ros J, Bellí G, Cabiscol E. Redox control and oxidative stress in yeast cells. Biochim Biophys Acta. 2008;1780:1217-35.

6. Lushchak VI. Oxidative stress in yeast. Biochemistry (Mosc). 2010;75:281-96.

7. Morano KA, Grant CM, Moye-Rowley WS. The response to heat shock and oxidative stress in Saccharomyces cerevisiae. Genetics. 2012;190:1157-95.

8. Papadakis MA, Workman CT. Oxidative stress response pathways: Fission yeast as archetype. Crit Rev Microbiol. 2014. doi:10.3109/104084X.2013.870968.

9. Miskei M, Karányi Z, Pócsi I. Annotation of stress-response proteins in the aspergilli. Fungal Genet Biol. 2009;46:S105-20.

10. Collinson LP, Dawes IW. Inducibility of the response of yeast cells to peroxide stress. J Gen Microbiol. 1992;138:329-35.

11. Flattery-O'Brien J, Collinson LP, Dawes IW. Saccharomyces cerevisiae has an inducible response to menadione which differs from that to hydrogen peroxide. J Gen Microbiol. 1993;139:501-7.

12. Berry DB, Gasch AP. Stress-activated genomic expression changes serve a preparative role for impending stress in yeast. Mol Biol Cell. 2008;19:4580-7. 
13. Berry DB, Guan Q, Hose J, Haroon S, Gebbia M, Heisler LE, Nislow C, Giaever $\mathrm{G}$, Gasch AP. Multiple means to the same end: the genetic basis of acquired stress resistance in yeast. PLoS Genet. 2011;7, e1002353.

14. Zakrzewska A, van Eikenhorst G, Burggraaff JE, Vis DJ, Hoefsloot H, Delneri D, Oliver SG, Brul S, Smits GJ. Genome-wide analysis of yeast stress survival and tolerance acquisition to analyze the central trade-off between growth rate and cellular robustness. Mol Biol Cell. 2011;22:4435-46.

15. Gasch AP, Spellman PT, Kao CM, Carmel-Harel O, Eisen MB, Storz G, Botstein $D$, Brown PO. Genomic expression programs in the response of yeast cells to environmental changes. Mol Biol Cell. 2000;11:4241-57.

16. Chen D, Toone WM, Mata J, Lyne R, Burns G, Kivinen K, Brazma A, Jones N, Bähler J. Global transcriptional responses of fission yeast to environmental stress. Mol Biol Cell. 2003;14:214-29.

17. Enjalbert B, Smith DA, Cornell MJ, Alam I, Nicholls S, Brown AJ, Quinn J. Role of the Hog1 stress-activated protein kinase in the global transcriptional response to stress in the fungal pathogen Candida albicans. Mol Biol Cell. 2006;17:1018-32.

18. Roetzer A, Gregori C, Jennings AM, Quintin J, Ferrandon D, Butler G, Kuchler K, Ammerer G, Schüller C. Candida glabrata environmental stress response involves Saccharomyces cerevisiae Msn2/4 orthologous transcription factors. Mol Microbiol. 2008;69:603-20.

19. Shiozaki K, Russell P. Conjugation, meiosis, and the osmotic stress response are regulated by Spc1 kinase through Atf1 transcription factor in fission yeast. Genes Dev. 1996;10:2276-88.

20. Wilkinson MG, Samuels M, Takeda T, Toone WM, Shieh JC, Toda T, Millar JB, Jones N. The Atf1 transcription factor is a target for the Sty 1 stress-activated MAP kinase pathway in fission yeast. Genes Dev. 1996;10:2289-301.

21. Enjalbert B, Nantel A, Whiteway M. Stress-induced gene expression in Candida albicans: absence of a general stress response. Mol Biol Cell. 2003;14:1460-7.

22. Smith DA, Nicholls S, Morgan BA, Brown AJ, Quinn J. A conserved stressactivated protein kinase regulates a core stress response in the human pathogen Candida albicans. Mol Biol Cell. 2004;15:4179-90.

23. Brauer MJ, Huttenhower C, Airoldi EM, Rosenstein R, Matese JC, Gresham D, Boer VM, Troyanskaya OG, Botstein D. Coordination of growth rate, cell cycle, stress response, and metabolic activity in yeast. Mol Biol Cell. 2008;19:352-67.

24. Slavov N, Airoldi EM, van Oudenaarden A, Botstein D. A conserved cell growth cycle can account for the environmental stress responses of divergent eukaryotes. Mol Biol Cell. 2012;23:1986-97.

25. Chen D, Wilkinson CR, Watt S, Penkett CJ, Toone WM, Jones N, Bähler J. Multiple pathways differentially regulate global oxidative stress responses in fission yeast. Mol Biol Cell. 2008;19:308-17.

26. Lawrence $\mathrm{CL}$, Maekawa H, Worthington JL, Reiter W, Wilkinson CR, Jones N Regulation of Schizosaccharomyces pombe Atf1 protein levels by Sty1mediated phosphorylation and heterodimerization with Pcr1. J Biol Chem. 2007;282:5160-70.

27. Sansó M, Gogol M, Ayté J, Seidel C, Hidalgo E. Transcription factors Pcr1 and Atf1 have distinct roles in stress- and Sty1-dependent gene regulation. Eukaryot Cell. 2008;7:826-35.

28. Eshaghi M, Lee JH, Zhu L, Poon SY, Li J, Cho KH, Chu Z, Karuturi RK, Liu J, Genomic binding profiling of the fission yeast stress-activated MAPK Sty 1 and the bZIP transcriptional activator Atf1 in response to $\mathrm{H}_{2} \mathrm{O}_{2}$. PLoS One. 2010;5, e11620.

29. Jakab Á, Antal K, Kiss Á, Emri T, Pócsi I. Increased oxidative stress tolerance results in general stress tolerance in Candida albicans independently of stress-elicited morphological transitions. Folia Microbiol (Praha). 2014;59:333-40.

30. Bennett JW. Aspergillus: a primer for the novice. Med Mycol. 2009;47:S5-S12

31. Klich MA. Health effects of Aspergillus in food and air. Toxicol Ind Health. 2009;25:657-67.

32. Kniemeyer O. Proteomics of eukaryotic microorganisms: The medically and biotechnologically important fungal genus Aspergillus. Proteomics. 2011:11:3232-43.

33. Buzina W. Aspergillus-classification and antifungal susceptibilities. Curr Pharm Des. 2013:19:3615-28.

34. Culleton H, McKie V, de Vries RP. Physiological and molecular aspects of degradation of plant polysaccharides by fungi: what have we learned from Aspergillus? Biotechnol J. 2013;8:884-94.
35. Lee YM, Kim MJ, Li H, Zhang P, Bao B, Lee KJ, Jung JH. Marine-derived Aspergillus species as a source of bioactive secondary metabolites. Mar Biotechnol (NY). 2013;15:499-519.

36. Pócsi I, Miskei M, Karányi Z, Emri T, Ayoubi P, Pusztahelyi T, Balla G, Prade RA. Comparison of gene expression signatures of diamide, $\mathrm{H}_{2} \mathrm{O}_{2}$ and menadione exposed Aspergillus nidulans cultures-linking genome-wide transcriptional changes to cellular physiology. BMC Genomics. 2005;6:182.

37. Chauhan N, Latgé JP, Calderone R. Signalling and oxidant adaptation in Candida albicans and Aspergillus fumigatus. Nat Rev Microbiol. 2006:4:435-44.

38. Etxebeste $\mathrm{O}$, Ugalde U, Espeso EA. Adaptative and developmental responses to stress in Aspergillus nidulans. Curr Protein Pept Sci. 2010;11:704-18.

39. Hartmann T, Sasse C, Schedler A, Hasenberg M, Gunzer M, Krappmann S. Shaping the fungal adaptome-stress responses of Aspergillus fumigatus. Int J Med Microbiol. 2011;301:408-16.

40. Fréalle E, Aliouat-Denis CM, Delhaes L, Hot D, Dei-Cas E. Transcriptomic insights into the oxidative response of stress-exposed Aspergillus fumigatus. Curr Pharm Des. 2013;19:3713-37

41. Abad A, Fernández-Molina JV, Bikandi J, Ramírez A, Margareto J, Sendino J, Hernando FL, Pontón J, Garaizar J, Rementeria A. What makes Aspergillus fumigatus a successful pathogen? Genes and molecules involved in invasive aspergillosis. Rev Iberoam Micol. 2010;27:155-82.

42. Reverberi M, Ricelli A, Zjalic S, Fabbri AA, Fanelli C. Natural functions of mycotoxins and control of their biosynthesis in fungi. Appl Microbiol Biotechnol. 2010;87:899-911.

43. Hong SY, Roze LV, Linz JE. Oxidative stress-related transcription factors in the regulation of secondary metabolism. Toxins (Basel). 2013;5:683-702.

44. Montibus M, Pinson-Gadais L, Richard-Forget F, Barreau C, Ponts N: Coupling of transcriptional response to oxidative stress and secondary metabolism regulation in filamentous fungi. Crit Rev Microbiol 2013, [Epub ahead of print].

45. Aguirre J, Ríos-Momberg M, Hewitt D, Hansberg W. Reactive oxygen species and development in microbial eukaryotes. Trends Microbiol. 2005;13:111-8.

46. Hagiwara D, Asano Y, Yamashino T, Mizuno T. Characterization of bZip-type transcription factor AtfA with reference to stress responses of conidia of Aspergillus nidulans. Biosci Biotechnol Biochem. 2008;72:2756-60.

47. Hagiwara D, Asano Y, Marui J, Yoshimi A, Mizuno T, Abe K. Transcriptional profiling for Aspergillus nidulans HogA MAPK signaling pathway in response to fludioxonil and osmotic stress. Fungal Genet Biol. 2009;46:868-678.

48. Balázs A, Pócsi I, Hamari Z, Leiter É, Emri T, Miskei M, Oláh J, Tóth V, Hegedűs N, Prade RA, Molnár M, Pócsi I. AtfA BZIP-type transcription factor regulates oxidative and osmotic stress responses in Aspergillus nidulans. Mol Genet Genom. 2010;283:289-303.

49. Lara-Rojas F, Sánchez O, Kawasaki L, Aguirre J. Aspergillus nidulans transcription factor AtfA interacts with the MAPK SakA to regulate general stress responses, development and spore functions. Mol Microbiol. 2011;80:436-54

50. Bok JW, Wiemann P, Garvey GS, Lim FY, Haas B, Wortman J, Keller NP: Illumina identification of RsrA, a conserved $\mathrm{C}_{2} \mathrm{H} 2$ transcription factor coordinating the NapA mediated oxidative stress signaling pathway in Aspergillus. BMC Genomics 2014, 15:1011. [Epub ahead of print].

51. Sakamoto K, Arima TH, Iwashita K, Yamada O, Gomi K, Akita O. Aspergillus oryzae atfB encodes a transcription factor required for stress tolerance in conidia. Fungal Genet Biol. 2008;45:922-32.

52. Sakamoto K, Iwashita K, Yamada O, Kobayashi K, Mizuno A, Akita O, Mikami $\mathrm{S}$, Shimoi H, Gomi K. Aspergillus oryzae atfA controls conidial germination and stress tolerance. Fungal Genet Biol. 2009:46:887-97.

53. Wong Sak Hoi J, Lamarre C, Beau R, Meneau I, Berepiki A, Barre A, Mellado E, Read ND, Latgé JP. A novel family of dehydrin-like proteins is involved in stress response in the human fungal pathogen Aspergillus fumigatus. Mol Biol Cell. 2011;22:1896-906

54. Hagiwara D, Suzuki S, Kamei K, Gonoi T. The role of AtfA and HOG MAPK pathway in stress tolerance in conidia of Aspergillus fumigatus. Fungal Genet Biol. 2014;73:138-49.

55. Nathues E, Joshi S, Tenberge KB, von den Driesch M, Oeser B, Bäumer N, Mihlan M, Tudzynski P. CPTF1, a CREB-like transcription factor, is involved in the oxidative stress response in the phytopathogen Claviceps purpurea and modulates ROS level in its host Secale cereale. Mol Plant Microbe Interact. 2004;17:383-93.

56. Yamashita K, Shiozawa A, Watanabe S, Fukumori F, Kimura M, Fujimura M. ATF-1 transcription factor regulates the expression of $c c \mathrm{c}-1$ and cat-1 genes 
in response to fludioxonil under OS-2 MAP kinase in Neurospora crassa. Fungal Genet Biol. 2008;45:1562-9.

57. Guo M, Guo W, Chen Y, Dong S, Zhang X, Zhang H, Song W, Wang W, Wang $Q$, Lv R, Zhang Z, Wang Y, Zheng X. The basic leucine zipper transcription factor Moatf1 mediates oxidative stress responses and is necessary for full virulence of the rice blast fungus Magnaporthe oryzae. Mol Plant Microbe Interact. 2010;23:1053-68.

58. Van Nguyen T, Kröger C, Bönnighausen J, Schäfer W, Bormann J. The ATF/ CREB transcription factor Atf1 is essential for full virulence, deoxynivalenol production, and stress tolerance in the cereal pathogen Fusarium graminearum. Mol Plant Microbe Interact. 2013;26:1378-94.

59. Qi X, Guo L, Yang L, Huang J. Foatf1, a bZIP transcription factor of Fusarium oxysporum f. sp. Cubense, is involved in pathogenesis by regulating the oxidative stress responses of Cavendish banana (Musa spp.). Phys Mol Plant Pathol. 2013;84:76-85.

60. Nimmanee $P$, Woo PC, Vanittanakom P, Youngchim S, Vanittanakom N. Functional analysis of atfA gene to stress response in pathogenic thermal dimorphic fungus Penicillium marneffei. PLoS One. 2014;9, e111200.

61. Szilágyi M, Miskei M, Karányi Z, Lenkey B, Pócsi I, Emri T. Transcriptome changes initiated by carbon starvation in Aspergillus nidulans. Microbiology. 2013;159:176-90.

62. Pusztahelyi T, Klement E, Szaji E, Klem J, Miskei M, Karányi Z, Emri T, Kovács S, Orosz G, Kovács KL, Medzihradszky KF, Prade RA, Pócsi I. Comparison of transcriptional and translational changes caused by long-term menadione exposure in Aspergillus nidulans. Fungal Genet Biol. 2011;48:92-103.

63. Yin WB, Reinke AW, Szilágyi M, Emri T, Chiang YM, Keating AE, Pócsi I, Wang CC, Keller NP. bZIP transcription factors affecting secondary metabolism, sexual development and stress responses in Aspergillus nidulans. Microbiology. 2013;159:77-88.

64. Han KH, Prade RA. Osmotic stress-coupled maintenance of polar growth in Aspergillus nidulans. Mol Microbiol. 2002:43:1065-78.

65. Chang PK, Scharfenstein LL, Luo M, Mahoney N, Molyneux RJ, Yu J, Brown RL, Campbell BC. Loss of msnA, a putative stress regulatory gene, in Aspergillus parasiticus and Aspergillus flavus increased production of conidia, aflatoxins and kojic acid. Toxins (Basel). 2011;3:82-104.

66. Hong SY, Roze LV, Wee J, Linz JE. Evidence that a transcription factor regulatory network coordinates oxidative stress response and secondary metabolism in aspergilli. Microbiologyopen. 2013;22:144-60.

67. Vogel C, Silva GM, Marcotte EM. Protein expression regulation under oxidative stress. Mol Cell Proteomics. 2011;10:M111.009217.

68. Montañés FM, Pascual-Ahuir A, Proft M. Repression of ergosterol biosynthesis is essential for stress resistance and is mediated by the Hog1 MAP kinase and the Mot3 and Rox1 transcription factors. Mol Microbiol. 2011;79:1008-23.

69. Campos EG, Jesuino RS, Dantas Ada S, Brígido Mde M, Felipe MS. Oxidative stress response in Paracoccidioides brasiliensis. Genet Mol Res. 2005;4:409-29.

70. Kroll K, Pähtz V, Kniemeyer O. Elucidating the fungal stress response by proteomics. J Proteomics. 2014;97:151-63.

71. Chen YA, McKillen DJ, Wu S, Jenny MJ, Chapman R, Gross PS, Warr GW, Almeida JS. Optimal CDNA microarray design using expressed sequence tags for organisms with limited genomic information. BMC Bioinformatics. 2004;5:191.

72. Baidya S, Duran RM, Lohmar JM, Harris-Coward PY, Cary JW, Hong SY, Roze LV, Linz JE, Calvo AM. VeA is associated with the response to oxidative stress in the aflatoxin producer Aspergillus flavus. Eukaryot Cell. 2014;13:1095-103.

73. Wu D, Oide S, Zhang N, Choi MY, Turgeon BG. ChLae1 and ChVel1 regulate T-toxin production, virulence, oxidative stress response, and development of the maize pathogen Cochliobolus heterostrophus. PLoS Pathog. 2012;8, e1002542.

74. Yang $\mathrm{Q}$, Chen $\mathrm{Y}, \mathrm{Ma}$ Z. Involvement of $\mathrm{Bc} \mathrm{C}$ eA and $\mathrm{BcV}$ elB in regulating conidiation, pigmentation and virulence in Botrytis cinerea. Fungal Genet Biol. 2013:50:63-71.

75. Gunawardana Y, Niranjan M. Bridging the gap between transcriptome and proteome measurements identifies post-translationally regulated genes. Bioinformatics. 2013;29:3060-6.

76. Thön M, Al-Abdallah Q, Hortschansky P, Brakhage AA. The thioredoxin system of the filamentous fungus Aspergillus nidulans: impact on development and oxidative stress response. J Biol Chem. 2007;282:27259-69.

77. Thön M, Al Abdallah Q, Hortschansky P, Scharf DH, Eisendle M, Haas H, Brakhage AA. The CCAAT-binding complex coordinates the oxidative stress response in eukaryotes. Nucleic Acids Res. 2010;38:1098-113.

78. Gasch AP. The environmental stress response: a common yeast response to diverse environmental stresses. Top Curr Genet. 2003;1:11-70.
79. Kovács Z, Szarka M, Kovács S, Boczonádi I, Emri T, Abe K, Pócsi I, Pusztahelyi T. Effect of cell wall integrity stress and RImA transcription factor on asexual development and autolysis in Aspergillus nidulans. Fungal Genet Biol. 2013:54:1-14.

80. Pusztahelyi T, Pócsi I. Functions, cooperation, and interplays of the vegetative growth signaling pathway in the Aspergilli. J Mycol. 2013;2013:832521.

81. Mutoh N, Nakagawa CW, Yamada K. The role of catalase in hydrogen peroxide resistance in fission yeast Schizosaccharomyces pombe. Can J Microbiol. 1999:45:125-9.

82. Li JR, Yu P. Expression of $\mathrm{Cu}, \mathrm{Zn}$-superoxide dismutase gene from Saccharomyces cerevisiae in Pichia pastoris and its resistance to oxidative stress. Appl Biochem Biotechnol. 2007;136:127-39.

83. Guan Q, Haroon S, Bravo DG, Will JL, Gasch AP. Cellular memory of acquired stress resistance in Saccharomyces cerevisiae. Genetics. 2012;192:495-505

84. Sansó M, Vargas-Pérez I, García P, Ayté J, Hidalgo E. Nuclear roles and regulation of chromatin structure by the stress-dependent MAP kinase Sty1 of Schizosaccharomyces pombe. Mol Microbiol. 2011;82:542-54.

85. Kanoh J, Watanabe Y, Ohsugi M, lino Y, Yamamoto M. Schizosaccharomyces pombe gad7 ${ }^{+}$encodes a phosphoprotein with a bZIP domain, which is required for proper G1 arrest and gene expression under nitrogen starvation. Genes Cells. 1996;1:391-408.

86. Vivancos AP, Jara M, Zuin A, Sansó M, Hidalgo E. Oxidative stress in Schizosaccharomyces pombe: different $\mathrm{H}_{2} \mathrm{O}_{2}$ levels, different response pathways. Mol Genet Genomics. 2006;276:495-502.

87. Subramaniam R, Rampitsch C. Towards systems biology of mycotoxin regulation. Toxins (Basel). 2013;5:675-82.

88. Roze LV, Chanda A, Wee J, Awad D, Linz JE. Stress-related transcription factor AtfB integrates secondary metabolism with oxidative stress response in aspergilli. J Biol Chem. 2011;286:35137-48.

89. Yin WB, Amaike S, Wohlbach DJ, Gasch AP, Chiang YM, Wang CC, Bok JW, Rohlfs M, Keller NP. An Aspergillus nidulans bZIP response pathway hardwired for defensive secondary metabolism operates through aflR. Mol Microbiol. 2012;83:1024-34.

90. Cary JW, Harris-Coward PY, Ehrlich KC, Di Mavungu JD, Malysheva SV, De Saeger S, Dowd PF, Shantappa S, Martens SL, Calvo AM. Functional characterization of a veA-dependent polyketide synthase gene in Aspergillus flavus necessary for the synthesis of asparasone, a sclerotium-specific pigment. Fungal Genet Biol. 2014;64:25-35.

91. Chiang YM, Oakley CE, Ahuja M, Entwistle R, Schultz A, Chang SL, Sung CT, Wang CC, Oakley BR. An efficient system for heterologous expression of secondary metabolite genes in Aspergillus nidulans. J Am Chem Soc. 2013;135:7720-31.

92. Bok JW, Hoffmeister D, Maggio-Hall L, Murillo R, Glasner JD, Keller NP. Genomic mining for Aspergillus natural products. Chem Biol. 2006;13:31-7.

93. Nakazawa T, Ishiuchi K, Praseuth A, Noguchi H, Hotta K, Watanabe K. Overexpressing transcriptional regulator in Aspergillus oryzae activates a silent biosynthetic pathway to produce a novel polyketide. ChemBioChem. 2012;13:855-61.

94. Daniel G, Nilsson T, Pettersson B. Intra- and Extracellular Localization of Lignin Peroxidase during the Degradation of Solid Wood and Wood Fragments by Phanerochaete chrysosporium by Using Transmission Electron Microscopy and Immuno-Gold Labeling. Appl Environ Microbiol. 1989;55:871-81.

95. Leiter E, Marx F, Pusztahelyi T, Haas H, Pócsi I. Penicillium chrysogenum glucose oxidase - a study on its antifungal effects. J Appl Microbiol. 2004;97:1201-9.

96. Sokol-Anderson ML, Brajtburg J, Medoff G. Amphotericin B-induced oxidative damage and killing of Candida albicans. J Infect Dis. 1986;154:76-83.

97. Papp G, Horváth E, Mike N, Gazdag Z, Belágyi J, Gyöngyi Z, Bánfalvi G, Hornok L, Pesti M. Regulation of patulin-induced oxidative stress processes in the fission yeast Schizosaccharomyces pombe. Food Chem Toxicol. 2012;50:3792-8.

98. Mike N, Papp G, Certik M, Czibulya Z, Kunsági-Máté S, Ember I, Vágvölgyi C, Pesti M, Gazdag Z. Regulation of cytotoxic, non-estrogenic, oxidative stressinduced processes of zearalenone in the fission yeast Schizosaccharomyces pombe. Toxicon. 2013;73:130-43.

99. Alpsoy L, Yalvac ME. Key roles of vitamins $A, C$, and $E$ in aflatoxin B1-induced oxidative stress. Vitam Horm. 2011;86:287-305.

100. Markus JT, Hohmann S. The osmotic stress response of Saccharomyces cerevisiae. Top Curr Genet. 2003;1:121-200. 
101. Calvo AM, Wilson RA, Bok JW, Keller NP. Relationship between secondary metabolism and fungal development. Microbiol Mol Biol Rev. 2002;66:447-59.

102. Affeldt KJ, Brodhagen M, Keller NP. Aspergillus oxylipin signaling and quorum sensing pathways depend on g protein-coupled receptors. Toxins (Basel). 2012;4:695-717.

103. Rodríguez-Urra AB, Jiménez C, Nieto MI, Rodríguez J, Hayashi H, Ugalde U. Signaling the induction of sporulation involves the interaction of two secondary metabolites in Aspergillus nidulans. ACS Chem Biol. 2012;7:599-606.

104. Yu JH, Hamari Z, Han KH, Seo JA, Reyes-Dominguez Y, Scazzocchio C. Double-joint PCR: a PCR-based molecular tool for gene manipulations in filamentous fungi. Fungal Genet Biol. 2004;41:973-81.

105. Kwon NJ, Garzia A, Espeso EA, Ugalde U, Yu JH. FlbC is a putative nuclear $\mathrm{C} 2 \mathrm{H} 2$ transcription factor regulating development in Aspergillus nidulans. Mol Microbiol. 2010;77:1203-19.

106. Park HS, Yu JH. Multi-copy genetic screen in Aspergillus nidulans. Methods Mol Biol. 2012;944:183-90.

107. Barratt RW, Johnson GB, Ogata WN. Wild-type and mutant stocks of Aspergillus nidulans. Genetics. 1965;52:233-46.

108. Pusztahelyi T, Pócsi I, Kozma J, Szentirmai A. Aging of Penicillium chrysogenum cultures under carbon starvation: I: morphological changes and secondary metabolite production. Biotechnol Appl Biochem. 1997;25:81-6.

109. Chomczynski P. A reagent for the single-step simultaneous isolation of RNA, DNA and proteins from cell and tissue samples. Biotechniques. 1993:15:536-7.

110. Pócsi I, Leiter E, Kwon NJ, Shin KS, Kwon GS, Pusztahelyi T, Emri T, Abuknesha RA, Price RG, Yu JH. Asexual sporulation signalling regulates autolysis of Aspergillus nidulans via modulating the chitinase ChiB production. J Appl Microbiol. 2009;107:514-23.

111. Ritchie ME, Silver J, Oshlack A, Silver J, Holmes M, Diyagama D, Holloway A, Smyth GK. A comparison of background correction methods for two-colour microarrays. Bioinformatics. 2007;23:2700-7.

112. Bolstad BM, Irizarry RA, Astrand M, Speed TP. A comparison of normalization methods for high density oligonucleotide array data based on bias and variance. Bioinformatics. 2003;19:185-93.

113. Smyth GK. Limma: linear models for microarray data. In: Gentleman R, Carey V, Dudoit S, Irizarry R, Huber W, editors. Bioinformatics and Computational Biology Solutions using $R$ and Bioconductor. New York: Springer; 2005. p. 397-420.

114. Inglis DO, Binkley J, Skrzypek MS, Arnaud MB, Cerqueira GC, Shah P, Wymore F, Wortman JR, Sherlock G. Comprehensive annotation of secondary metabolite biosynthetic genes and gene clusters of Aspergillus nidulans, A. fumigatus, A. niger and A. oryzae. BMC Microbiol. 2013;13:91.

115. Team C. R: A language and environment for statistical computing. Vienna, Austria: R Foundation for Statistical Computing; 2013.

\section{Submit your next manuscript to BioMed Central and take full advantage of:}

- Convenient online submission

- Thorough peer review

- No space constraints or color figure charges

- Immediate publication on acceptance

- Inclusion in PubMed, CAS, Scopus and Google Scholar

- Research which is freely available for redistribution 